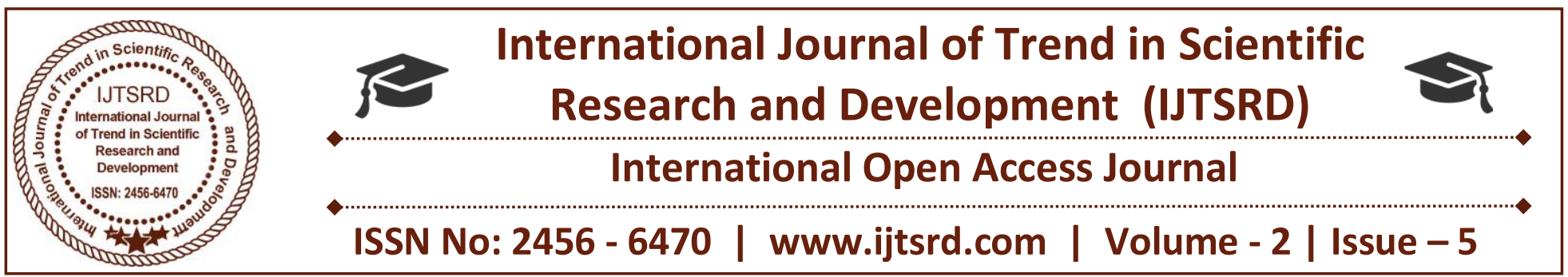

\title{
Quality Management of NH 31 from Etah to Kasganj in U.P.
}

\author{
Pushpendra Singh ${ }^{1}$, Mr. Mohd. Suhail Khan ${ }^{2}$ \\ ${ }^{1}$ Student, ${ }^{2}$ Assistant Professor, ${ }^{1,2}$ Department of Civil Engineering, \\ Al-Falah School of Engineering and Technology, Al-Falah University, \\ Dhauj, Faridabad, Haryana, India
}

\begin{abstract}
Quality systems entail having the organizational structure, responsibilities, procedures, processes and resources for implementing quality management such that there is a guiding framework to ensure that every time a process is performed the same information, method, skills and controls are used and practiced in a consistent manner. Construction firms have been continually struggling with its implementation. Historically construction has been an industry reluctant to implement change. Consequently, it has remained behind where it should be on the implementation of TQM. When a state highway physical works contract is issued for tender, it will be assessed to determine the quality assurance level. Transit will select the level for the contract using a formula designed to determine the relative complexity of the contract.
\end{abstract}

NH-31 Extension is the newly declared National Highway of this region which starts form Etah to Kasganj. Its length is $97.48 \mathrm{Km}$. It is an important link road between Mainpuri and Bareilly. International tourist forms different countries commute through this road. It is very important road form cultural, commercial and strategic point of view; so, it has to be kept in good motor able condition.

This report is based on a study conducted on NH-31 to identify those factors that hinder the implementation of TQM principles in the actual field operations of a construction jobsite. These inhibitive factors were identified through a literature review and a survey ofNH-31 road.

Keywords: Quality Assurance, Construction, Transport.

\section{INTRODUCTION}

\subsection{General}

That quality assurance is mandatory for all physical works on state highways. The quality system adopted by the contractor to meet this requirement must be based on (but in some cases may not fully comply with) NZS ISO 9000. Transit has adopted a two-level concept that relates the quality assurance requirement applying to a contract to the quality assurance level that is assigned to that contract. The following table shows how this works:

Contract QA Level Minimum QA Requirement High Compliance with Standard TQS1 together with a Contract Quality Plan Normal Compliance with Standard TQS2 together with a Contract Quality Plan In addition to the above, requires tendering authorities, when undertaking roading physical works that qualify for financial assistance, to engage contractors who comply with its own quality assurance requirements. These may be found in Land Transport NH Programme and Funding Manual the Standards TQS1 and TQS2 are explained briefly as follows:

\section{$>$ Transit NH Quality Standard TQS1}

This standard requires the contractor to maintain a quality system that incorporates most of the elements of NZS ISO 9000 but with less comprehensive and stringent requirements. It requires third party certification by an approved certification body. This is explained in more detail in section 3 of these notes. The Standard TQS1 also requires a Contract Quality Plan to be prepared for each contract undertaken.

$>$ Transit NH Standard TQS2 
This standard requires the contractor to develop and work to a contract quality plan for each contract. The contractor is also required to operate a simple quality system during the contract period, which provides the supporting structure for the contract quality plan. There is no certification requirement for compliance with Standard TQS2. However, the Engineer will carry out surveillance during the contract, which may include checks of the contractor's system and records.

$>$ Application of Standard Tqs2

When a state highway physical works contract is issued for tender, it will be assessed to determine the quality assurance level. Transit will select the level for the contract using a formula designed to determine the relative complexity of the contract. The criteria used in this formula include:

$>$ technical requirements of the work;

$>$ contract value and duration;

$>$ level of assessed level of risk of aspects of the project;

$>$ project management requirements of the work;

$>$ public impact and level of stakeholder liaison required;

$>$ safety aspects, and traffic control of the work; and

$>$ Environmental management requirements.

For contracts assessed as having a normal quality assurance level, compliance with Standard TQS2 is the minimum requirement. The Combined Working Party on Road Construction, Road Maintenance and Structures originally developed this standard for Transit. It has been designed specifically for use on state highway physical works contracts involving road construction, road maintenance, and structures activities. The terms, and their definitions, used in this standard are consistent with those of NZS ISO 8402:1994 and NZS 3910:1998.

Contractors operating quality assurance systems to NZS ISO 9000 will meet the quality assurance requirements provided they prepare a Contract Quality Plan that meets the requirements of Element 2 Clause 4 of this Standard. Any specific requirements contained or referenced in the specifications contained within the contract must also be addressed. These requirements need to be considered during the preparation of the Tender, to assess capability to meet these requirements, and again prior to the commencement of any work

\subsection{Objective}

In the ancient period, river transport was much faster and easier than road transport, particularly considering the road construction cost and the variation in the transportation capacity. The Romans built stone roads in North Africa and Europe to support their military operations. Later the Arabs built roads that were covered with tar. Tar was obtained from petroleum, by the chemical techniques of destructive distillation.

The roads were constructed by preparing earthworks and lifting the road foundation at the center for the water drainage. The road construction techniques were improved by the study of road traffic, stone thickness, road alignment, and the slope gradients. The initial road construction materials were basically stones that were laid in a regular, compact design, and covered with smaller stones to produce a solid layer. The construction materials testing were simply a visual inspection, without the use of complicated and accurate test equipment.

National Highway Road construction, Highway Road construction, Express Highway and Interstate Road construction are various forms of roads that are constructed by us. They all are designed and built for primary use by vehicles with different loads. Depending on the need and intensity, different materials and mixtures are utilized to fulfill road construction contract.

National Highways form backbone to any country and India maintains a remarkable network of such highways. We've helped the country immensely in its endeavors to maintain a fine connectivity with rest of the country by taking up and finishing construction works of National Highways. With decades of experience, expertise and required workforce, we've been consistently supporting the cause of national highway construction in India.

\subsection{Scope and area of project}

India has one of the largest road networks in the world aggregating to 3.34 million $\mathrm{Km}$ of roadways spread across the length and breadth of the country. The roads are primarily made of bitumen, with some Indian National highways having concrete roads.

The concept of expressway roads is also catching up in India, and the Mumbai-Pune expressway and Delhi-Gurgaon expressways are the finest example. 
The country's road network consists of Expressways, National Highways, State Highways, Major District Roads, Other District Roads and Village Roads with the following length distribution:

Table 1.1 District Roads and Village Roads length distribution

\begin{tabular}{|c|c|}
\hline National Highways/Expressways & $66754 \mathrm{~km}$ \\
\hline State Highways & $128000 \mathrm{~km}$ \\
\hline Major and other District Roads & $470000 \mathrm{~km}$ \\
\hline Rural Roads & $2650000 \mathrm{~km}$ \\
\hline
\end{tabular}

In India, too, like other parts of the world, the advent of the automobile found a similarly primitive natural road system that has only over a full century been brought up to the standard called for by automotive travel. The Grand Trunk road by Sher Shah Suri was one of the only few motor able roads in the country. However, Indian road making has gone through a revolution in the last $40-50$ years. Continuous expansion, maintenance and improvement have been a part of this revolution. Efforts are now been made to improve the existing National Highways not only by strengthening and rehabilitation of existing assets but also by constructing new roads and bridges over missing links, improvement of low grade sections and widening to 4-lanes. The work of modernization of the system through construction of some expressways is also in progress. Currently, in the 10th Plan, the Ministry of Surface Transport outlines a massive of job of nation building. It would decide the phased removal of deficiencies in the existing $\mathrm{NH}$ network in tune with traffic needs for $10-15$ years with emphasis on high-density corridors for four lining. It would bring in highway-user oriented project planning in identifying package of project section-wise rather than isolated stretches. Also, greater attention would be given to the rehabilitation and reconstruction of dilapidated bridges for the safety of the traffic. Along with the modernization of road construction technology for speedy execution and quality assurance, there would be continuous efforts in engineering measures to improve road safety and conservation of energy. However, perhaps the most noteworthy objective is integrating the development plans with Railways and other modes of transport. North eastern region would be the first to track on with this objective.

Now, to be a little futuristic, India plans to experiment with rubber roads. Or a step further, India might begin something on the line of Canada's all-weather road to the Arctic Ocean.

However, all these ambitious planning falls back on funding support. Development work on the National Highways is currently done through budgetary support. To improve the position of availability of funds, steps are being taken in this direction. Cess on petrol and diesel has been levied to make funds available for Highway infrastructure development. Funds are also obtained from externally funding agencies like World Bank. Asian development Bank, OECF etc. for projects in the Highway sector. Amendments have been made in the National Highway Act to encourage private sector participation in funding of road projects on BOT (Build-Operate and Transfer) basis.

Roads also worked as inroads to the development of civilizations, and provided human beings a corridor of communication for venturing out to newer frontiers of achievements. The Government's policy and programs also have laid emphasis with the construction of backbone of India, the poverty alleviation, generation of employment and income opportunities and provision of infrastructure and basic facilities to meet the needs of rural poor. For realizing these objectives, self-employment and wage employment programs continued to pervade in one form or other. As a measure to strengthen the grass root level democracy, the Government is constantly endeavoring to empower Panchayati-Raj Institutions in terms of functions, powers and finance. Grama sabha, NGOs, Self-Help Groups and PRIs have been accorded adequate role to make participatory democracy meaningful and effective.

\subsection{Research Methodology}

Providing and laying of stress absorbing Membrane over a cracked road surface, with crack Width below $6 \mathrm{~mm}$ after cleaning with mechanical Broom, using modified binder complying with clause 521, sprayed at the rate of $9 \mathrm{~kg} 10 \mathrm{sqm}$ and spreading $5.6 \mathrm{~mm}$ crushed stone aggregates @0.11cum per 10sqm with hydraulic chip spreader sweeping the surface for Uniform spread of aggregates and surface finished to Conform to clause 902.

Providing and applying tack coat with bitumen emulsion Using emulsion pressure distributor at the rate of $0.20 \mathrm{~kg} / \mathrm{m}^{\wedge} 2$ on the prepared bituminous/ surface cleaned with Mechanical broom. Providing 
and laying bituminous macadam $75 \mathrm{~mm}$. Thick with 100-120 TPH hot plant producing an over- Rage output of 75 tones per hour using crushed Aggregates of specified grading premixed with Bituminous binder 60/70@3.3\% of mix, transported, to site lad over a previously prepared surface with Pavers finisher to the required grade, level and Alignment and rolled as per clause 501.6 and 501.7 to Achieve the desired compaction, add $15 \%$ undulations.

Providing and laying semi dense bituminous Concrete with 100-120 TPH batch type HMP Producing an Average output of 75 tones per hour using crushed Aggregates of specified grading premixed with bituminous Binder @5 percent of mix and filler transport

Construction of embankment with approved material, obtained from borrow pits with all lifts and leads transporting to site spreading grading to required slope and Compacting to meet requirement of table 300-2.

Pavement center line markings $10 \mathrm{~cm}$ wide with hot applied. Thermoplastic material completes as per drawing and technical Specification clause 803 and irc-35.

Construction of drain both side of road in $\mathrm{km} 01$ and 02. Supply\& fixing of $80 \mathrm{~mm}$ thick I shaped mechanically Compressed inter locking cement concrete pavers block Manufactured by high pressure by $\&$ controlled vibration, Machine having plan dimension $200 *(160+120 \mathrm{~mm})$ with mini Mum $5 \mathrm{~mm}$ thick topping of O.P cement mixed with $25 \%$ marble Powder. The completion strength of concrete pavers blocks Shall not be less than $30 \mathrm{MPa} \& 4.5 \mathrm{~kg} / \mathrm{no}$. including cost all Material lab our T\&P etc. required for proper completion of Work as directed by engineer-in-change. Over $20 \mathrm{~cm}$ GSB, $25 \mathrm{~cm}$ WMM $\& 3 \mathrm{~cm}$ sand cushion.

\section{LITERATURE REVIEW}

Construction has long been considered dangerous work. In addition, the construction industry is under constant scrutiny for quality of work. In the interest of improving quality performance in the construction industry, a literature review was performed on construction research articles to find out if this integrated management system concept has been investigated.

\section{Muhammad Yousuf, Shou Qing Wang, Mohammed Dulaimi}

It is important to manage the multifaceted risks associated with international construction projects, in particularin developing countries, not only to secure work but also to make profit. This research seeks to identify and evaluate these risks and their effective mitigation measures and to develop a risk management framework which the international investors/ developers/ contractors can adopt when contracting construction work-in developing countries. A survey was conducted and twenty-eight critical risks were identified, categorized into three (country, market and project) hierarchical levels and their criticality evaluated and ranked. For each of the identified risks, practical mitigation measures have also been proposed and evaluated. Almost all mitigation measures have been perceived by the survey respondents as effective. A risk model, named Alien Eyes' Risk Model, which shows the hierarchical levels of the risks and the influence relationship among the risks, is also proposed. Based on the findings, a qualitative risk mitigation framework was finally proposed which will benefit the risk management of construction project in developing countries.

\section{Discussion of Results:}

Twenty-eight critical risks associated with international construction projects in developing countries were identified and categorized into three hierarchy levels (Country, Market and Project). Of which, 22 were evaluated as Critical or Very Much Critical based on a 7-degree rating system. The top 11 critical risks are: Approval and Permit, Change in Law, Justice Reinforcement, Local Partner's Creditworthiness, Political Instability, Cost Overrun, Corruption, Inflation and Interest Rates, Government Policies, Government Influence on Disputes and Termination of JV. The risks at Country level are more critical than that at Market level and the latter are more critical than that in Project level. For each of the identified risks, practical mitigation measures were provided and evaluated. Almost all of the mitigation measures were perceived by the respondents to the survey as effective using a 7degree rating system. It is suggested that when mitigating a specific risk, the measures with higher effectiveness should be given a higher priority. Considering the higher criticalities of higher risk hierarchy levels, the mitigation measures should also be prioritized by the higher risk hierarchy level, i.e. 
the risks at higher hierarchy level should be mitigated first with higher priority with their respective more effective mitigation measures. A risk model, named Alien Eyes' Risk Model, was proposed which shows the three risk hierarchy levels and the influence relationship among risks. This model will enable better categorizing of risks and representing the influence relationship among risks at different hierarchy levels as well as revealing the mitigating sequence/priority of risks. A qualitative risk mitigation framework integrating the key findings of the research was also proposed providing detailed risk management strategies and procedure that international especially Singaporean firms, could adopt. The proposed framework is practical and relatively easy to apply. Although the survey sample is relatively small, the authors believe that the survey results are still meaningful. Nevertheless, more survey samples could be included so as to make the results more

valid.

\section{Akintola Akintoye, George McIntosh, Eamon Fitzgerald}

The results of a questionnaire survey of supply chain collaboration and management in the top the UK construction industry contractors. The results indicate the formation of a significant number of partnerships/ collaborative agreements between contractors, suppliers and clients following the publication of the Latham (1994) and Egan (1997) reports. It appears that construction supply chain management (SCM) is still at its infancy but some awareness of the philosophy is evident. Contractors identified improved production planning and purchasing as key targets for the application of SCM in construction. Barriers to success included: workplace culture, lack of senior management commitment, inappropriate support structures and a lack of knowledge of SCM philosophy. Training and education at all levels in the industry are necessary to overcome these barriers.

\section{Discussion of Results:}

Supply chain collaboration and management has been used in many industries to gain competitive advantage. From the retail industry to the automotive and the agricultural industries, the philosophy has examples of successful applications. Japanese car manufacturers have enjoyed the benefits of a close relationship with suppliers, enabling a close two-way \#ow of information and benefits. Following this success, The Supply Chain Council developed a supply chain operations reference model in order for deferent industries to apply the philosophy and improve their own strategy. The construction industry has been relatively slow to adopt SCM as a management strategy (Table 2) in part to be due to the well documented unique nature of the construction process and bespoke product with various stakeholders and a variety of objectives. The contractors' opinions were surveyed because of their pivotal role in the construction supply chain, previously referred to. It was regarded as a timely exercise in view of the interest and energy devoted to the debate on new forms of UK procurement, which emphasizes the virtues of partnering, long-term and non-adversarial relationships as the key to substantial productivity gains for the Industry. The study reveals that contractors are more oriented towards clients rather than their suppliers in the supply chain. They have more arrangements with clients than with suppliers and a higher proportion of the relationships with clients are contractual. Owing to the aggressive business mentality of the industry and then on-trusting climate, contractors have tendencies to pay more attention to clients who provide their work load. The study suggests that contractors, regard suppliers on a par with employees and sub-contractors, i.e. as suppliers of a service they have the opportunity to dispense with largely as they please. The study also shows that there is a high correlation between the timing of publication of the Latham Report (1994) and the Egan Report (1997) with the increased number of partnership arrangements in the construction"rm's supply chain, both upstream and downstream. There has been an increase in the number of collaborative relationships following publication of these reports, but their influence cannot be quantified with any degree of precision. Open tendering was increasingly being regarded as outdated; the vast majority of contractors preferred to build partnerships with the client. Supply chain collaboration and management is an important element of construction with nearly all of the respondents rating it as being important or critical for future success. Although improved quality assurance is not a key objective for SCM development, contractors do seek a better quality of service from suppliers. The problems in implementing successful supply chain collaboration and management within the UK construction industry are at present associated with an in appropriate traditional culture and the unique features of the organizational structure. Trust * a major requirement for successful implementation * is only now being actively cultivated by the industry. 
The lack of senior management commitment, the lack of appropriate support structures and the widespread ignorance of supply chain philosophy, must all be addressed if construction is to emulate other industries. Appropriate training and education, at all levels of the industry, is required to overcome these barriers.

\section{Burcu Akinci, Frank Boukamp, Chris Gordon, Daniel Huber, Catherine Lyons, Kuhn Park.}

Defects experienced during construction are costly and preventable. However, inspection programs employed today cannot adequately detect and manage defects that occur on construction sites, as they are based on measurements at specific locations and times, and are not integrated into complete electronic models. Emerging sensing technologies and project modeling capabilities motivate the development of a formalism that can be used for active quality control on construction sites. In this paper, we outline a process of acquiring and updating detailed design information, identifying inspection goals, inspection planning, as-built data acquisition and analysis, and defect detection and management. We discuss the validation of this formalism based on four case studies.

\section{Discussion of Results:}

Reality capture technologies have matured sufficiently to be utilized for as-built data collection on construction sites. These technologies can be leveraged to improve project quality control processes. Formalism is needed to utilize these technologies effectively and to analyze the data collected from these instruments to enable active quality control. Our formalism for using advanced sensor systems and integrated project models for active quality control includes five basic process steps: creating as-planned project model information, identifying inspection goals, inspection planning, data collection, and defect detection and management. Our utilization of the formalism on four construction sites suggests that the generality of the overall approach and its possible technical effectiveness in data collection and deviation detection. Future research includes further refining the algorithms implemented in support of this formalism and incorporation of other reality capture technologies to the automated quality control framework. In addition, we hope to perform detailed studies on assessing the cost effectiveness of the formalism described in this report.

\section{K. N. JHA! \& K. C. IYER!!}

The reasons for the underperformance of the quality of Indian construction projects were studied to suggest possible remedial measures. A preliminary survey identified 55 attributes responsible to impact quality performance of the projects. Statistical analysis of questionnaire responses on the attributes resulted into two distinct sets of success and failure attributes. Further analyses of individual sets of success attributes and failure attributes separately grouped them into fewer critical success and failure factors. The critical success factors obtained were: project manager's competence; top management's support; monitoring and feedback by project participants; interaction among project participants; and owners' competence. The factors that adversely affected the quality performances of projects were: conflict among project participants; hostile socioeconomic environment; harsh climatic condition; PM's ignorance \& lack of knowledge; faulty project conceptualization; and aggressive competition during tendering. Analyses also led to the conclusion that the extent of contribution of various success factors varies with the current performance ratings of the project. Project manager's competence and top management support/are found to contribute significantly in enhancing the quality performance of a construction project. As in the manufacturing industry, the study establishes that management plays an important role in achieving quality even in construction projects.

\section{Discussion of Results:}

Compliance with quality specifications is an important performance measure of any construction project. The repercussions and consequences of poor quality can be a loss in productivity; additional expenditure by way of rework and repair; loss of reputation, leading to loss in market share; and eventually being put out of business. The importance of performing work to the expected quality level has been recognized since ancient times. It has become even more relevant in the context of a barrier-free world. With the opening up of the economy to the outside world, Indian companies are going experiencing stiff competition, not only from domestic players alone but also from multinational companies. To help companies cope with the quality demands imposed by customers, through attending to the attributes affecting the quality of construction projects, has been the motivation behind this study. Through interviews of construction professionals and by searching the relevant literature, 55 project 
attributes were compiled. Out of these 55 attributes, 28 - referred to as success attributes in the study were found to help achieve the desired quality, whereas the presence of 22 - referred to as failure attributes - were found to affect adversely to the achievement of the desired quality performance. The conclusions derived from the study are given below.

Project manager's competence; top management support and their competence; interaction between project participants; owners' competence; and monitoring and feedback by project participants are the factors having positive contributions to achieving the desired quality level, while factors such as conflict among project participants; hostile socio-economic and climatic condition; ignorance and lack of knowledge; some project specific factors; and aggressive competition at the tender stage are found to adversely affect the quality performances of projects.

The extent of the contribution of various success factors varies with the performance ratings of the project. A project manager's competence is observed to be the most significant factor at almost all levels of the quality performance rating. The other two factors that have a significant contribution in improving the project quality are found Critical Factors Affecting Quality Performance in Construction Projects 1169 to be 'top management support' and 'interaction between project participants'. The study re-establishes some of the earlier findings in the developing countries' context, that essential factors to achieve good quality are the 'human element rather than machinery' and 'good communication among people'. In addition, it also establishes that, similar to the production industry, in the construction industry the role of management is more important than the workforce itself in achieving quality. The results of the study prove to be closer to Juran's philosophy that middle management (project manager and his team in this case) play a more important role in most stages of the project, although the top management's role becomes more significant in further enhancing the level of quality when the existing level is already high.

\section{Ali Jaafari}

This project concerns the challenges of applying the principles of total quality management to construction projects, particularly from the stand point of the human factor. The work is based on two major studies carried out in 1993-1995, at industry and project level respectively. The last study particularly targeted construction workers and their perception of the usefulness of the QA systems in place on case projects, and whether or not there were concurrent attempts to achieve workers' empowerment on these projects. The findings are that: (i) while the quality assurance obligations to clients (under the ISO9000's series) are being met through the existing systems (which are largely quality control based), the benefits to contractors in terms of continuous improvement and cost savings have not materialized; (ii) the view from the construction pit on the usefulness of the current generation of quality assurance systems is in marked contrast to the aims and objectives of quality assurance Standards and TQM principles; (iii) the communication processes within industry and projects remain poor; (iv) in the rush to become 'quality endorsed' the training needs of the rank and file of the workforce have generally been forgotten; and (v) better strategies are needed to 'sell' the TQM concept to the rank and file in industry and develop means of implementing TQM at project level effectively, thereby achieving workers' empowerment.

\section{Discussion of Results:}

The quality assurance 'revolution' unleashed in the construction industry since the early 1990s is not delivering the promised efficiencies and has in many instances degenerated into a paper-based formality. One reason is the lack of a national focus on educating the rank and file of the industry as to the necessity of, and goals for, embracing TQM-based construction practices. As a result, there is a growing cynicism within the industry concerning the usefulness and relevance of the so-called QA methods. The processes of communication within the industry as a whole and within projects remain poor and neglected. In the rush to push the 'quality' along and secure certification the rank and file of the workforce and their training needs have been largely neglected. The quality plans typically developed and used in the construction industry have had a clientcompliance focus only and have not been cost effective in the sense that these have not resulted in any tangible savings, have not tapped into the body of experience held within the rank and file, and have failed to convince the core opinion within the workforce of the perceived value of TQM and continuous improvement in general. The author attempted to sketch a more orderly process of introducing 'quality' in the construction industry. It was shown that the current move to force 'quality' on 
the industry without concern about the characteristics, structure, hereditary environment and the unique way that the industry behaves, was doomed to fail. The results from the field surveys confirm these findings and show that there are no 'quick fixes' in this complex industry.

\section{NH-31 COMPONENTS}

\subsection{Earthwork}

The Process of earthworks is to excavate the existing land to a suitable level so that road construction may begin. The earthworks can take the form of either excavation in the form of cuts or the construction of embankments to carry an elevated highway. Normally in a road design project, both will be necessary and movement of earth from one part of the site to the next will be necessary. This should be done with as little waste created or as little extra material required as disposal or collection is expensive.

\subsubsection{Earthwork for embankment and sub-grade to be placed against sloping ground}

Where and embankment/sub-grade is to be placed /scarified before placing the embankment/sub-grade material. Extra earthwork involved in benching or due to plugging/scarifying etc. shall be considered incidental to the work.

For wet conditions benches with slightly inward fall and subsoil drains at the lowest point shall be provided as per the drawings before the fill is placed against sloping ground.

Where the contract requires construction of transverse subsurface drain at the cut-fill interface, work on the same shall be carried out in proper sequence with the embankment and sub grade work as approved by the Engineer.

\subsubsection{Earthwork over existing road surface}

Where the embankment is to be placed over an existing road surface, the work shall be carried out as indicated below.

$>$ If the existing road surfaced is of granular or bituminous type and lies within $1 \mathrm{~m}$ of the new sub-grade level, the same shall be scarified to a depth of $50 \mathrm{~mm}$ or more if specifies, so as to provided ample bond between the old and new material ensuring that ate least $500 \mathrm{~mm}$ potion below the top of new sub-grade level is compacted to the desired density.
If the existing road surface is of cement concrete type and lies within $1 \mathrm{~m}$ of the new sub-grade level the same shall be removed completely.

If the level difference between the existing road surface and the new formation level is more than 1 $\mathrm{m}$, the existing surface shall be permitted to stay in place without any modification.

\subsubsection{Embankment and sub-grade around structures}

To avoid interface with the construction of abutments, wing walls or return walls of culvert/bridges structures, the Contractor shall let point to be determined by the Engineer suspend work on embankment forming approaches to such structures, until such time as the construction of the latter is sufficiently advanced to permit the completion of approaches without the risk of damage to the structure.

Unless directed otherwise, the filling around culverts, bridges and other structures' up to a distance of twice the height of the road form the back of the abutment shall be carried out independent of the work the on the main embankment. The fill material shall not be placed against Engineer but in any case, not until the concrete or masonry has been in position for 14 days. The embankment and sub-grade shall be brought up simultaneously and in equal layers on each side of the structure to avoid displacement and unequal pressure. The sequence of work in this regard shall be got approved form the Engineer.

The material used for backfill shall not be an organic soil or highly plastic clay having plasticity index and liquid limit more than 20 and 40 respectively when tested according to IS:2720 (Part 5). Filling behind abutments and wind walls for all structures shall conform to the general guidelines given in Appendix 6 of IRC: 78 (Standard Specification and Code of practice for Road Bridges-Section VII) in respect of the type of material, the extent of backfill, its laying and compaction etc. The fill material shall be deposited in horizontal layers in loose thickness and compacted thoroughly to the requirements of Table 300-2.

Where the provision of any filter medium is specified behind the abutment, the same shall be laid in layers simultaneously with the laying of fill material. The material used for filter shall conform to the requirements for filter medium spelt out in clause 
International Journal of Trend in Scientific Research and Development (IJTSRD) ISSN: 2456-6470

2502/309.3.2 (B) unless otherwise specified in the contract. Where it may be impracticable to use conventional rollers, the compaction shall be carried out by appropriate mechanical means such as small vibratory rollers, plate compactor or powers rammer. Care shall be taken to see that the compaction equipment's does not hit or come too close to any structural member so as to cause any damage to them or excessive pressure against the structure.

\subsection{Granular Sub-Base}

Layers in the construction of a mortar less pavement: A.) Subgrade B.) Subbase C.) Base course D.) Paver base E.) Pavers F.) Fine-grained sand in highway engineering, subbase is the layer of aggregate material laid on the subgrade, on which the base course layer is located. It may be omitted when there will be only foot traffic on the pavement, but it is necessary for surfaces used by vehicles.

Subbase is often the main load-bearing layer of the pavement. Its role is to spread the load evenly over the subgrade. The materials used may be either unbound granular, or cement-bound. The quality of subbase is very important for the useful life of the road and can outlive the life of the surface, which can be scrapped off and after checking that the subbase is still in good condition, a new layer can be applied

\subsubsection{Scope}

This work shall consist of laying and compacting well-graded material on prepared sub-grade : in accordance with the requirements of these specification.

The material shall be laid in one or more layers as sub-base or lower sub-base and upper sub-base (termed as sub-base hereinafter) as necessary according to lines, grades and cross-sections shown on the drawings or as directed by the engineer.

\subsubsection{Materials}

The material to be used for the work shall be natural sand morrow gravel crushed stone or combination thereof depending upon the grading required.

Materials like crushed concrete brick metal and kankar may be allowed only with the specific approval of the engineering. The material shall be free from organic or other deleterious constituents and confirmed to one of the three gradings given below.
Table 3.1 Grading for Close-Graded Granular Sub-Base Material

\begin{tabular}{|c|c|c|c|}
\hline \multirow{2}{*}{$\begin{array}{c}\text { IS Sieve } \\
\text { Designatio } \\
n\end{array}$} & \multicolumn{3}{|c|}{$\begin{array}{c}\text { Percent by weight passing the IS } \\
\text { sieve }\end{array}$} \\
\cline { 2 - 4 } & $\begin{array}{c}\text { Grading } \\
\text { I }\end{array}$ & $\begin{array}{c}\text { Grading } \\
\text { II }\end{array}$ & $\begin{array}{c}\text { Grading } \\
\text { III }\end{array}$ \\
\hline $75.0 \mathrm{~mm}$ & 100 & - & - \\
\hline $53.0 \mathrm{~mm}$ & & 100 & - \\
\hline $26.5 \mathrm{~mm}$ & $55-75$ & $50-80$ & 100 \\
\hline $9.50 \mathrm{~mm}$ & & & \\
\hline $4.75 \mathrm{~mm}$ & $10-30$ & $15-35$ & $25-45$ \\
\hline $2.36 \mathrm{~mm}$ & & & \\
\hline $0.425 \mathrm{~mm}$ & & & \\
\hline $0.075 \mathrm{~mm}$ & $<10$ & $<10$ & $<10$ \\
\hline $\begin{array}{c}\text { CBR Value } \\
\text { (Minimum) }\end{array}$ & 30 & 25 & 20 \\
\hline
\end{tabular}

While the gradings in table are in respect of close graded granular sub base materials one each form maximum particle size of $75 \mathrm{~mm}, 53 \mathrm{~mm}$, and $26.5 \mathrm{~mm}$ the corresponding grading for the course graded materials for each of three maximum particle sizes are given at table given below table (2.2) The grading to be adopted are for a project shall be as specified in the contract.

\section{Table 3.2 Grading for Coarse Graded Granular} Sub-Base material

\begin{tabular}{|c|c|c|c|}
\hline \multirow{2}{*}{$\begin{array}{c}\text { IS Sieve } \\
\text { Designatio } \\
\text { n }\end{array}$} & \multicolumn{3}{|c|}{$\begin{array}{c}\text { Percent by weight passing the IS } \\
\text { sieve }\end{array}$} \\
\cline { 2 - 4 } & $\begin{array}{c}\text { Grading } \\
\text { I }\end{array}$ & $\begin{array}{c}\text { Grading } \\
\text { II }\end{array}$ & $\begin{array}{c}\text { Grading } \\
\text { III }\end{array}$ \\
\hline $75.0 \mathrm{~mm}$ & 100 & - & - \\
\hline $53.0 \mathrm{~mm}$ & & 100 & - \\
\hline $26.5 \mathrm{~mm}$ & $55-75$ & $50-80$ & 100 \\
\hline $9.50 \mathrm{~mm}$ & & & $25-45$ \\
\hline $4.75 \mathrm{~mm}$ & $10-30$ & $15-35$ & \\
\hline $2.36 \mathrm{~mm}$ & & & $<10$ \\
\hline $0.425 \mathrm{~mm}$ & & & 20 \\
\hline $0.075 \mathrm{~mm}$ & $<10$ & $<10$ & \\
\hline $\begin{array}{l}\text { CBR Value } \\
(\text { Minimum) }\end{array}$ & 30 & 25 & \\
\hline
\end{tabular}

\subsubsection{Physical requirements}

The material shall have a 10 percent fines value of 50 $\mathrm{kN}$ or more (for sample in soaked condition) when tested in compliance with BS: 812 (Part 111). The water absorption value of the coarse aggregated shall be determined as per IS: 2386 (Part 3); if this value is greater than 2 percent, the soundness test shall be carried out on the material delivered to site as per IS: 
383 For Grading II and III materials, the CBR shall be determined at the density and moisture content likely to be developed in equilibrium conditions which shall be taken as being the density relating to a uniform air voids contents of 5 per cent.

\subsubsection{Strength of sub-base}

It shall be ensured prior to actual execution that the material to be used in the sub base satisfies the requirements of $\mathrm{CBR}$ and other physical requirements when compacted and finished.

When directed by the Engineer, this shall be verified by performing CBR tests in the laboratory as required on specimens remolded at field dry density and moisture content and any other tests for the "quality" of materials, as may be necessary.

\subsection{Wet mix Macadam Sub-base/Base}

Aggregates used are of the smaller sizes, varies between the $4.75 \mathrm{~mm}$ to $20 \mathrm{~mm}$ sizes and the binders (stone dust or quarry dust having PI (Plasticity Index) not less than $6 \%$ ) are premixed in a batching plant or in a mixing machine. Then they are brought to the site for overlaying and compaction.

The PI (plasticity Index) of the binding material is kept low because it should be a sound and non-plastic material. If the plasticity index is more then there are the chances of the swelling and more water retention properties. So, this value should be kept in mind.

\subsubsection{Scope}

This work shall consist of laying and compacting clean crushed graded aggregate and granular material, premixed with water to a dense mass on a prepared sub grad/sub-base/base or existing pavement as the case may be in accordance with the requirement so these specifications. The material shall be laid in one or more layers as necessary to lines, grades and crosssections shown on the approved drawing or as directed by the Engineer

\subsubsection{Physical requirements}

Course aggregated shall be crushed stone, if crushed gravel/shingle is used, not less than 90 per cent by weight of the gravel/shingle pieces retained on $4.75 \mathrm{~mm}$ sieve shall have at least two fractured faces. The aggregates shall conform to the physical requirements set forth in Table 3.1 below.
Table 3.3 Physical requirements of coarse aggregates for wet mix macadam for sub-base/base courses.

\begin{tabular}{|c|c|c|c|}
\hline $\begin{array}{c}\text { S. } \\
\text { no }\end{array}$ & Test & $\begin{array}{c}\text { Tests } \\
\text { Method }\end{array}$ & $\begin{array}{c}\text { Requirem } \\
\text { ents }\end{array}$ \\
\hline 1 & $\begin{array}{c}\text { Los Angeles } \\
\text { abrasion value or }\end{array}$ & $\begin{array}{c}\text { IS:2386 } \\
\text { (Part-4) }\end{array}$ & $\begin{array}{c}40 \text { percent } \\
\text { (Max.) }\end{array}$ \\
\hline & $\begin{array}{c}\text { Aggregated Impact } \\
\text { value }\end{array}$ & $\begin{array}{c}\text { IS:2386 } \\
\text { (Part-4) or } \\
\text { IS:5640 }\end{array}$ & $\begin{array}{c}\text { 30 Percent } \\
\text { (Max.) }\end{array}$ \\
\hline 2 & $\begin{array}{c}\text { Combined } \\
\text { Flakiness and } \\
\text { Elongation indices } \\
\text { (Total) }\end{array}$ & $\begin{array}{c}\text { IS:2386(P } \\
\text { art-1) }\end{array}$ & $\begin{array}{c}\text { 30 Percent } \\
\text { (Max.) } * *\end{array}$ \\
& \multicolumn{3}{|c}{} \\
\hline
\end{tabular}

*Aggregate may satisfy requirements of either of the two tests.

** To determine this combined proportion the flaky stone, form a representative sample should first be separated out. Flakiness index is weight of flaky stone metal divided by weight of stone sample. Only the elongated particles be separated index so found are added up. If the water absorption value of the coarse aggregate is greater than 2 percent, the soundness test shall be carried out on the material delivered to site as per IS: 2386 (Part-5).

\subsubsection{Grading requirements: -}

The aggregates shall conform to the grading given in table 3.2

Table 3.4 Grading requirements of aggregates for wet mix macadam

\begin{tabular}{|c|c|c|}
\hline \multicolumn{2}{|c|}{ IS sieve Designation } & $\begin{array}{c}\text { Percent by weight passing } \\
\text { the IS Sieve }\end{array}$ \\
\hline 53.00 & $\mathrm{Mm}$ & 100 \\
\hline 45.00 & $\mathrm{Mm}$ & $95-100$ \\
\hline 26.50 & $\mathrm{Mm}$ & - \\
\hline 22.40 & $\mathrm{Mm}$ & $60-80$ \\
\hline 11.20 & $\mathrm{Mm}$ & $40-60$ \\
\hline 4.75 & $\mathrm{Mm}$ & $25-40$ \\
\hline 2.36 & $\mathrm{Mm}$ & $15-30$ \\
\hline 600.00 & Micron & $8-22$ \\
\hline 75.00 & Micron & $0-8$ \\
\hline
\end{tabular}

Materials finer than 425 microns shall have plasticity index (PI) not exceeding 6 The final gradation approved within these limits shall well grade from coarse to fine and shall not vary from the low limit on one sieve to the high limit on the adjacent sieve or vice versa. 


\subsection{Prime Coat over Granular Base}

A prime coat is an application of a low viscosity asphalt to a granular base in preparation for an initial layer (or surface course layer) of asphalt.

\subsubsection{Scopes}

This work shall consist of the application of a single coat of low viscosity liquid bituminous material to a porous granular surface preparatory to the superimposition of bituminous treatment or mix.

\subsubsection{Materials}

Primer: The choice of a bituminous primer shall depend upon the porosity characteristics of the surface to be primed as classified in IRC: 16 these are: -

I. Surface of low porosity; such as wet mix macadam and water bound macadam.

II. Surface of medium porosity; such as cement stabilized soil base.

III. Surfaces of high porosity; such as a gravel base.

Primer viscosity: The type and viscosity of the primer shall comply with the requirements of IS 8887, as sampled and tested for bituminous in according with these standards. Guidance on viscosity and rate of spray is given table 4.1.

Table 3.5 Viscosity Requirement and Quantity of Liquid Bituminous Primer

\begin{tabular}{|c|c|c|}
\hline $\begin{array}{c}\text { Type of } \\
\text { surface }\end{array}$ & $\begin{array}{c}\text { Kinematics } \\
\text { Viscosity of } \\
\text { primer at } 60^{0} \\
\text { c(Centistokes) }\end{array}$ & $\begin{array}{c}\text { Quantity of } \\
\text { Liquid } \\
\text { Bituminous } \\
\text { Materials per 10 } \\
\text { sq.m (kg) }\end{array}$ \\
\hline $\begin{array}{c}\text { Low } \\
\text { porosity }\end{array}$ & $30-60$ & 6 to 9 \\
\hline $\begin{array}{c}\text { Medium } \\
\text { porosity }\end{array}$ & $70-140$ & 9 to 12 \\
\hline $\begin{array}{c}\text { High } \\
\text { Porosity }\end{array}$ & $250-500$ & 12 o 15 \\
\hline
\end{tabular}

Choice of primer: The primer shall be bituminous emulsion, complying with IS 8887 of a type and grade as specified in the contract or directed by the engineer. The use of medium curing cut back as per IS 217 shall be restricted only for sites at subzero temperature or for emergency applications as directed by the engineer.

\subsubsection{Weather and seasonal limitations}

Bituminous primer shall not be applied to a wet surface or during a dust storm or when the weather is foggy, rainy or windily or when the temperature in the shade is less than $10 \mathrm{c}$. surface which are to reserve emulsion primer should be dump, but no free or standing water shall be present.

\subsubsection{Construction}

At one time it was thought that a prime coat was an essential element of good asphalt pavement construction. However, asphalt prime materials and the gradation of aggregate bases have changed over the years and applications of prime are no longer necessary for most asphalt pavements. In fact, their use can be detrimental to pavement performance. This has led the Virginia Department of Transportation (VDOT), many state and municipal DOT's as well as other engineers to remove the requirement from their specifications. According to studies performed by The Asphalt Institute over the last 20+ years, few if any, pavement failures can be attributed to the lack of a prime coat.

\subsubsection{Equipment:}

The primer distributor shall be a self-propelled or towed bitumen pressure sprayer equipped for spraying the material uniformly at specified rates and temperatures. Hand spraying of small areas, inaccessible to the distributor or as directed by the engineer.

\subsubsection{Preparation of road surface:}

The surface to be primed shall be prepared as appropriate immediately prior to applying the primer the surface shall be carefully swept clean of dust and loose particle, care being taken not to disturb the interlocked aggregates. This is best achieved when the surface layer is slightly moist (lightly sprayed be kept moist the primer is applied.

\subsubsection{Application of bituminous primer}

The viscosity and rate of application of the primer shall be as specified in the contract, or as determined by site trials carried out as directed by the engineer. Where a geosynthetic is proposed for use. The bituminous primer shall be sprayed the primer will depend the spray bar and speed of forward movement. The contractor shall demonstrate at a spraying trial that the equipment and method to be used is capacity of production a uniform spray, with in the tolerances specified. 


\subsubsection{Curing of primer and opening to traffic}

A primed surface shall be allowed to cure for at least 24 hours or such other period as is found to be necessary to allow all the volatiles to evaporate before any sub sequent surface treatment or mix is laid. Any unabsorbed primer shall first be blotted with an application of sand, using the minimum quantity possible. A primed surface shall not be opened to traffic other than that necessary to lay the next course. A very thin layer of clean sand picking up under the wheels of the paver and the trucks delivering bituminous material to the paver.

\subsubsection{Track coat}

Over the primed surface, a track core should be applied in accordance provisions designs by govt. of India.

\subsubsection{Quality control of work}

For control of the quality of materials of supplied and the works carried out the relevant provisions shall apply.

\subsubsection{Arrangements for traffic}

During construction operation arrangements for traffic shall be made in accordance with the provisions designs by govt. of India.

\subsubsection{Measurements for payments}

Prime coat shall be measured in terms of surface area of application in square meters.

\subsubsection{Rate}

Payment shall be made on the basis of the provision of prime coat at an application rate of $0.6 \mathrm{~kg}$ per square meter with actual amount approved by the engineer after the preliminary trials taken by them.

\subsection{Tack Coat}

A tack coat is thin bituminous liquid asphalt, emulsion or cutback layer applied between HMA pavement lifts to promote bonding.

Adequate bonding between constructions lifts and especially between the existing road surface and an overlay is critical in order for the completed pavement structure to behave as a single unit and provide adequate strength. If adjacent layers do not bond to one another they essentially behave as multiple independent thin layers - none of which are designed to accommodate the anticipated traffic-imposed bending stresses.
Inadequate bonding between layers can result in delamination (debonding) followed by longitudinal wheel path cracking, fatigue cracking, potholes, and other distresses such as rutting that greatly reduce pavement life

\subsubsection{Scope}

This work shall consist of the application of a single coat of low viscosity liquid bituminous material to an existing bituminous road surface in the contract or instructed by the engineer.

\subsubsection{Materials}

The binder used for track coat shall be bitumen emulsion complying with IS 8887 of type and grade as specified in the contract or as directed by the engineer.

The use of cut back bitumen as per IS 217 shall be restricted only for sites at subzero temperature or for emergency applications as directed by the engineer,

\subsubsection{Weather and seasonal limitations}

Bituminous material shall not be applied to a wet surface or during a dust storm or when the weather is foggy, rainy or windy or when the temperature in the shade is less than $10 \mathrm{c}$.

Where the track coat consists of emulsion the surface is slightly damp, but not wet. Where the track coat is cut back of bitumen the surface shall be dry.

\subsubsection{Construction}

The pavement surface receiving the tack coat should be clean and dry to promote maximum bonding. Emulsified tack coat materials may be applied to cool and/or damp pavement, however, the length of time needed for the set to occur may increase (Flexible Pavements of Ohio, 2001[2]).

Since existing and milled pavements can be quite dirty and dusty, their surfaces should be cleaned off by sweeping or washing before any tack coat is placed, otherwise the tack coat material may bond to the dirt and dust rather than the adjacent pavement layers. This can result in excessive tracking of the tack coat material.

Construction vehicles and equipment pick up the tackdirt mixture on their tires and leave the existing roadway with little or no tack coat in the wheel paths 
Slippage cracking and delamination are distresses typically seen when cleanliness is lacking

\subsubsection{Equipment}

The track coat distributor shall be a self-propelled or towed bitumen pressure sprayer, equipped the material uniform at a specified rate. Hand sprayed of small areas, inaccessible the distributor, or in narrow strips, shall be sprayed with a pressure hand sprayer, or directed by the engineer.

\subsubsection{Preparation of base}

The surface on which the track coat is to be applied shall be clean and free from dust, dirt and any extraneous material and be otherwise prepared in according with the requirements of clauses 501.8 and 902 as appropriate. Immediately before the applications broom and high-pressure air jet or by other means directed by the engineer.

\subsubsection{Application of track coat}

The application of track coat shall be at the rate specified in the contract, and shall be applied uniformly. If be the rate specified in the contract then it shall be at the rate specified in table 500-2. The normal range of spraying

\section{Table 3.6 Rate of Application of Track Coat}

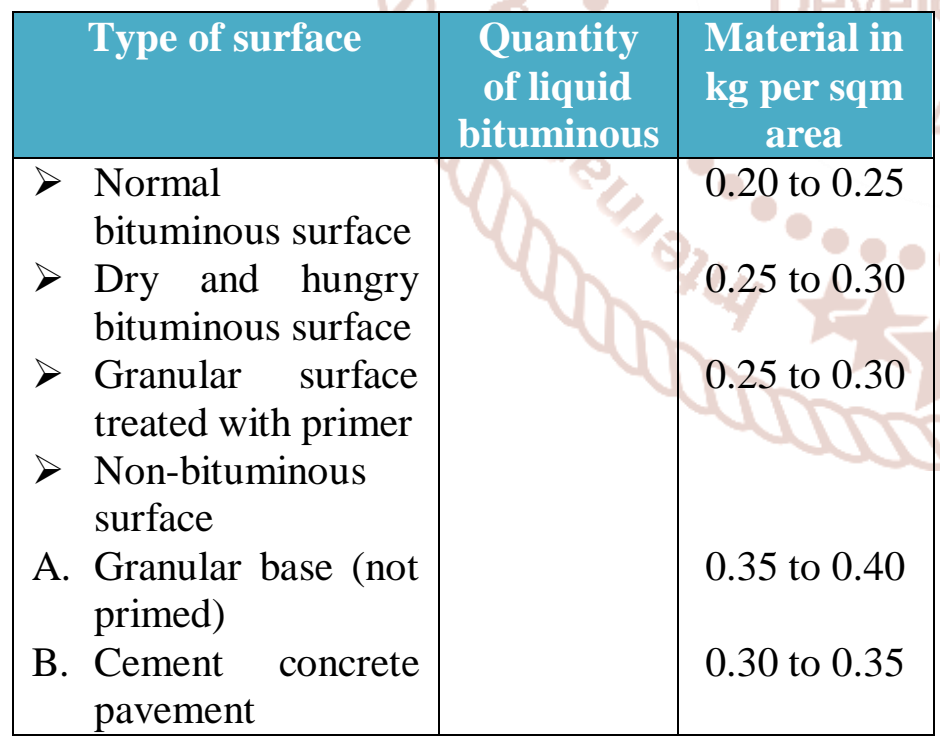

Temperature for a bituminous emulsion shall be $20 \mathrm{c}$ to $70 \mathrm{c}$ and for a cut back, $500 \mathrm{c}$ to $80 \mathrm{c}$ it RC $70 / \mathrm{MC}-70$ used where a geosynthetic is proposed for use, the provisions of clauses 703.3.2 and 703.4.4 shall apply the method of application of the track coat will depend on the type of equipment to be used size of nozzles, pressure at the spray bar and speed of forward movement .The contractor shall demonstrate at spraying trial that the equipment and method to be used capable of production a uniform spray with in the tolerances specified.

Where the material to receive an overlay is freshly laid bituminous layers that have not been subjected to traffic or contamination by dust a track coat is not mandatory where the overlay is completed within two days.

\subsubsection{Curing control of work}

The track coat shall be left to cure until all the volatiles have evaporated before any subsequent construction is started. No plant or vehicles shall be allowed on the track coat other than those essential for the construction.

\subsubsection{Quality control of work}

For control of the quality of materials supplied and the works carried out the relevant provision provisions designs by govt. of India.

\subsubsection{Arrangements for traffic.}

During the period of construction, arrangements for traffic shall be made in accordance with the provision provisions designs by govt. of India.

\subsubsection{Measurements for payments}

Track coat shall be measured in terms of surface area of applications in sq. meters.

\subsubsection{Rate}

The rate shall the cover the provision of track coat at $0.2 \mathrm{~kg}$. per square meter with the provision that the variance in actual quantity of bituminous used will be assessed and the payment adjusted accordingly

\subsection{Bituminous Macadam}

A pavement constructed by spreading two or more layers of crushed stone on a suitable base and pouring a bituminous binder on each

\subsubsection{Scopes}

This work shall consist of construction in a single course having $50 \mathrm{~mm}$ to $100 \mathrm{~mm}$ thickness or in multiple courses of compacted crushed aggregates premixed with a bituminous binder on a previously prepared base to the requirement of these specifications. 
International Journal of Trend in Scientific Research and Development (IJTSRD) ISSN: 2456-6470

\subsubsection{Materials}

\section{$>$ Bituminous:}

The bituminous shall be paving bituminous of penetration grade complying with Indian standard specification for "paving bituminous" IS: 73 and of the penetration indicated in table 6.2.

\section{$>$ Coarse aggregates:}

The course aggregates shall consist of crushed rock, crushed gravel or other hard material retained on the $2.36 \mathrm{~mm}$ sieve. They shall be clean, hard, and durable of cubical shape, free from dust and soft or friable matter, organ other deleterious matter. Where the contractor's selected source of aggregates has poor affinity for bitumen, as a condition for the approval of anti- stripping agents, as per the manufacture's recommendation, without additional payment. Before approval of the source the aggregates shall be tested for stripping.

The aggregates shall satisfy the physical requirements set forth in table 6.1.

Where crushed gravel is proposed for use as aggregates, not less than $90 \%$ by weight of the crushed material retained on the $4.75 \mathrm{~mm}$ sieve shall have at least two fractured faces.

\section{$>$ Fine aggregates:}

Fine aggregates shall consist of crushed or naturally occurring material or a combination of the two passing $2.36 \mathrm{~mm}$ sieve and retained on 75micron sieve. They shall be clean, hard durable, dry and free from dust, and soft or friable matter organic or other deleterious matter.

Table 3.7 Physical requirement for coarse aggregates for bituminous Macadam,

\begin{tabular}{|c|c|c|}
\hline Property & Test & Specification \\
\hline Flakiness & 1. Grain size analysis & Max $5 \%$ passing $0.075 \mathrm{~mm}$ sieve \\
\hline Shape & 2. flakiness and elongation index(combined) & $\operatorname{Max} 30 \%$ \\
\hline & 3. Los Angles Abrasion Value & $\operatorname{Max} 40 \%$ \\
\hline Primality & 4. Aggregates impact value ational Journal & $\operatorname{Max} 30 \%$ \\
\hline & 5. Soundness & \\
\hline Water & Sodium sulphate Tre & $\operatorname{Max} 12 \%$ \\
\hline absorption & Magnesium sulphate & $\operatorname{Max} 18 \%$ \\
\hline Shipping & 6. Water absorption Resealrch and & $\operatorname{Max} 2 \%$ \\
\hline & 7. Coating and stripping of bitumen aggregates & Minimum retained coating $95 \%$ \\
\hline Water & Mixture & \\
\hline Sensitivity & 8. Retained Tensile Strength & Min $80 \%$ \\
\hline
\end{tabular}

\section{Notes:}

1. IS 2386 part 1

2. IS 2386 part 1

(The elongation test to be done only to be nonflaky aggregates in the sample)

3. IS: 2386 part $4 *$

4. IS 2386 part 5

5. IS 2386 part 3

6. IS: 6241

7. The water sensitivity test is only to be carried out if the minimum retained counting in the stripping test is less than $95 \%$.

** Aggregates may satisfy requirement of either of these two tests.

\subsubsection{Aggregates grading and binder content:}

When tested in accordance with IS: 2386 part 1 (wet sieving method) the combines aggregates grading for the particular mixture shall fall within the limits shown in table 6.2 grading specified in the contact. The type and quantity of bitumen, an appropriate thickness is also indicated for each mixture type.

\subsubsection{Proportioning of material:}

The aggregates shall be proportioned and blended to produce a uniform mixture complying with the requirements of table 500-4. The binder content shall be within a tolerance of \pm 0.3 per cent by weight of total mixture when individual specimens are taken for quantity control tests in accordance with the provision specified by govt.

\subsubsection{Construction operations}

Bitumen road construction consists of various steps such as preparation of base course, application of bituminous coal, placement of bituminous mix, rolling and check for quality etc. 


\subsubsection{Weather and seasonal limitations}

A simulation model is applied to a long series (1918$65)$ of daily rainfall observations to produce an experimental series of operational records on the weather-sensitive portion of a road building project. These records are analyzed statistically for various periods of time within the normal construction season and the resulting statistics are examined for their potential usefulness in the management of road construction.

Table 3.8 composition bituminous macadam

\begin{tabular}{|c|c|c|}
\hline \multirow{6}{*}{$\begin{array}{c}\text { Mix designation } \\
\text { Nominal } \\
\text { aggregates size } \\
\text { Layer thickness } \\
\text { IS sieve }(\mathrm{mm})\end{array}$} & Grading 1 & Grading 2 \\
\hline & $40 \mathrm{~mm}$ & \multirow{5}{*}{$\begin{array}{c}19 \mathrm{~mm}, \\
50-75 \mathrm{~mm}\end{array}$} \\
\hline & $80 \quad 100 \mathrm{~mm}$ & \\
\hline & Cumulative & \\
\hline & \%by weight of & \\
\hline & $\begin{array}{c}\text { total aggregates } \\
\text { passing }\end{array}$ & \\
\hline 45 & 100 & 0 \\
\hline 37.5 & $90-100$ & \\
\hline 26.5 & $75-100$ & 100 \\
\hline 19 & $-\quad$ & $90-100$ \\
\hline 13.2 & $35-61$ & $56-88$ \\
\hline 4.75 & $13-22$ & 16.36 \\
\hline 2.36 & $4-19$ & $4-19$ \\
\hline 0.3 & $2-10$ & $2-10$ \\
\hline 0.075 & $0-8$ & $0-8$ \\
\hline Bituminous & $3.1-3.4$ & $3.3-3.5 \mathrm{e}$ \\
\hline $\begin{array}{l}\text { content } \% \text { by } \\
\text { weight of total }\end{array}$ & & \\
\hline & & \\
\hline Bituminous grade & 35 to 90 & 35 to 90 \\
\hline
\end{tabular}

Notes: 1 Appropriate bituminous content for condition in cooler area of initial may be up to $0.5 \%$ higher subjects to the approval of the engineer.

\subsubsection{Preparation of the base}

The base on which bituminous macadam is to be laid shall be prepared, shaped and compacted to be the required as specified or as directed by the engineer.

\subsubsection{Tack coat}

A tack coat in accordance with clause set by govt. shall be applied ad required by the contract documents or as directed by the engineer.

\subsubsection{Preparation and transportation of the mixture Spreading}

Pre-mixed bituminous materials shall be prepared in a hot mix plant of adequate capacity and capable of yielding a mix of proper and uniform quality with thoroughly coated aggregates. Appropriate mixing temperatures are given below in Table. The difference in temperature between the binder and aggregate shall at no time exceed $14^{\circ} \mathrm{C}$. In order to ensure uniform quality of the mix and better coating of aggregates, the hot mix plant shall be calibrated from time to time.

\begin{tabular}{|c|c|c|c|c|c|}
\hline $\begin{array}{l}\text { Bitumi } \\
\text { nous } \\
\text { penetr } \\
\text { ation }\end{array}$ & $\begin{array}{l}\text { Bitumi } \\
\text { nous } \\
\text { mixing } \\
\left({ }^{0} \mathrm{C}\right)\end{array}$ & $\begin{array}{l}\text { Aggre } \\
\text { gates } \\
\text { Mixin } \\
\mathrm{g}\left({ }^{\circ} \mathrm{C}\right)\end{array}$ & $\begin{array}{l}\text { Mixe } \\
\text { d } \\
\text { Mate } \\
\text { rial } \\
\left({ }^{\circ} \mathrm{C}\right)\end{array}$ & $\begin{array}{l}\text { Rolli } \\
\text { ng } \\
\left({ }^{\circ} \mathrm{C}\right)\end{array}$ & $\begin{array}{l}\text { Layi } \\
\text { ng } \\
\left({ }^{\circ} \mathrm{C}\right)\end{array}$ \\
\hline 35 & $\begin{array}{l}100- \\
170\end{array}$ & $\begin{array}{l}160- \\
175\end{array}$ & $\begin{array}{c}170 \\
\text { Maxi } \\
\text { mum }\end{array}$ & $\begin{array}{c}100 \\
\text { Mini } \\
\text { mum }\end{array}$ & $\begin{array}{c}130 \\
\text { Mini } \\
\text { mum }\end{array}$ \\
\hline 65 & $\begin{array}{l}150- \\
165\end{array}$ & $\begin{array}{r}150- \\
170\end{array}$ & $\begin{array}{c}165 \\
\text { Maxi } \\
\text { mum }\end{array}$ & $\begin{array}{c}90 \\
\text { Mini } \\
\text { mum }\end{array}$ & $\begin{array}{c}125 \\
\text { Mini } \\
\text { mum }\end{array}$ \\
\hline 90 & $\begin{array}{c}140- \\
160 \\
\text { na| }\end{array}$ & $\begin{array}{l}140- \\
165\end{array}$ & $\begin{array}{c}155 \\
\text { Maxi } \\
\text { mum }\end{array}$ & $\begin{array}{c}80 \\
\text { Mini } \\
\text { mum }\end{array}$ & $\begin{array}{c}115 \\
\text { Mini } \\
\text { mum }\end{array}$ \\
\hline
\end{tabular}

\subsection{Semi dense bituminous concrete}

Wearing course on roads carrying moderate traffic, generally less than $10 \mathrm{msa}$ Lesser binder content when compared to $\mathrm{BC}$

\subsubsection{Scope}

The clause specified the construction of semi dense bituminous concrete for use in wearing / binder and profile corrective course.

This work shall consist of construction in a multiple layers of semi dense bituminous concrete on a previously prepared bituminous bound surface a single layer shall be $25 \mathrm{~mm}$ to $100 \mathrm{~mm}$ in thickness.

\subsubsection{Material}

$>$ Bitumen the bitumen shall be paving bitumen of penetration grade complying with Indian standard specification for paving bitumen, IS: 73 and of the penetration indicated in table 7.2, for semi dense bituminous concrete or this bitumen as modified by one of the methods specified by govt. or as otherwise specified in the contract guidance on the selection of an appropriate grade of bituminous is given in the manual for construction and supervision of bituminous Works 
International Journal of Trend in Scientific Research and Development (IJTSRD) ISSN: 2456-6470

\section{Course aggregates}

The coarse aggregates shall be generally as specified in by govt. manuals. Except that the aggregates shall satisfy the physical required of table 7.1

\section{Filler}

Filler shall be generally as specified or where the aggregates fail to meet the requirements of the water sensitivity test in table 7.1 then 2 per cent by total weight of aggregates of hydrated lime shall be added without additional coat.

\section{Aggregates grading and binder content}

When tested in accordance with IS :2386 part 1 (wet sieving method) the combined grading of the coarse and fine aggregates and filler shall fall within the limits shown in table 7.2 for grading 1 or 2 as specified in the contract.
$>$ Minimum Stability

8.2

$\left(\mathrm{kN}\right.$ at $\left.60^{\circ} \mathrm{C}\right)$,

$>$ Flow

2-4

$>$ Compaction level (Number of blows) on each face

$>$ Per cent air voids

$>$ Per cent voids in mineral Aggregate VMA Table (VMA)

Per cent voids filled with bitumen 65-78 (VFB)

Loss of stability on immersion in Minimum $75 \%$ water at $60^{\circ} \mathrm{C}(\mathrm{ASTM} \mathrm{D} 1075)$

\section{5}

3-5

VMA Table

$65-78$

Minimum $75 \%$

\subsubsection{Requirements for the mixture}

A part from conformity with the grading and requirements for individual ingredients the mixture shall meet the requirements set out in table 7.3.

Physical Requirements for Coarse Aggregate for Semi Dense Bituminous Concrete Pavement Layers

\subsubsection{Mixture Design}

Table3.10 Physical requirement for course aggregate for semi dense bituminous Concrete pavement layers

\begin{tabular}{|c|c|c|}
\hline Property & Test & Specification \\
\hline Cleanliness(dust) & 1. Grain size analysis ${ }^{1}$ & Max 5\% Passing $0.075 \mathrm{~mm}$ sieve \\
\hline Particle Shape & 2. Flakiness and Elongation Index $(\text { Index })^{2}$ & $\operatorname{Max} 30 \%$ \\
\hline Strength* & $\begin{array}{l}\text { 3. Los Angeles Abrasion Value }{ }^{3} \text { nent } \\
\text { 4. Aggregated Impact Value }\end{array}$ & (1) $\quad \begin{array}{l}\operatorname{Max} 35 \% \\
\operatorname{Max} 27 \%\end{array}$ \\
\hline Polishing & 5. Polished Stone Value ${ }^{5}$ & Min 55 \\
\hline Durability & 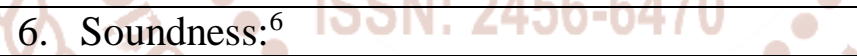 & $0 \times 2$ \\
\hline & Sodium Sulphate & $\operatorname{Max} 12 \%$ \\
\hline & Magnesium Sulphate & Max $18 \%$ \\
\hline Water Absorption & 7. Water Absorption & $\operatorname{Max} 2 \%$ \\
\hline Stripping & $\begin{array}{l}\text { 9. Coating and stripping of Bituminous } \\
\text { Aggregate Mixtures } 9\end{array}$ & Minimum Retained Coating 95\% \\
\hline Water Sensitivity & 8. Retained Tensile Strength ${ }^{8}$ & Min $80 \%$ \\
\hline
\end{tabular}

\section{Notes:}

1. IS: 2386 Part 1

2. IS 2386 Part 1 (The elongation test may be done only on non-flaky aggregates in the sample)

3. IS: 2386 Part 4

4. IS: 2386 Part 4

5. BS: 812 Part 114

*Aggregate may satisfy requirements of either of these two tests.

** The water sensitivity test is only required if the minimum retained coating in the stripping test is less than $95 \%$.
6. IS: 2386 Part 5

7. IS: 2386 Part 3

8. AASHTO T283**

9. IS: 6241

The requirements for minimum percent voids in mineral aggregate (VMA) are set out in Table 500-12.

\subsubsection{Binder content}

The binder content shall be optimized to achieve the requirements of the mixture set out in Table 500-16 
and the traffic volume as specified in the Contract. The Marshall method for determining the optimum binder content shall be adopted as described in the Asphalt Institute Manual MS-2, replacing the aggregates retained on the $26.5 \mathrm{~mm}$ sieve and retained on the $22.4 \mathrm{~mm}$ sieve, where approved by the Engineer.

Table 3.11 compositions of semi dense bituminous concrete Pavement layers

\begin{tabular}{|c|c|c|}
\hline Grading & 1 & 2 \\
\hline $\begin{array}{c}\text { Nominal aggregates } \\
\text { size }\end{array}$ & $13 \mathrm{~mm}$ & $10 \mathrm{~mm}$ \\
\hline Laver thickness & $35-40 \mathrm{~mm}$ & $25-30 \mathrm{~mm}$ \\
\hline IS sieve $^{1}(\mathrm{~mm})$ & $\begin{array}{c}\text { Cumulative } \% \\
\text { by weigh of } \\
\text { total aggregates } \\
\text { passing }\end{array}$ & \\
\hline 15 & & \\
\hline 110 & & \\
\hline 205 & & \\
\hline 19 & 100 & Elital \\
\hline 13.2 & 90-100 & 100 \\
\hline 9.5 & $70-90$ & $90-100$ \\
\hline 4.75 & $35-51$ & $35-51 / \mathrm{e}$ \\
\hline 2.36 & $24-39$ & $24-39$ \\
\hline 1.18 & $15-30$ & $15-30$ \\
\hline 0.6 & & \\
\hline 0.8 & $9-19$ & $9-19$ \\
\hline 0.15 & - & \\
\hline 0.075 & $3-8$ & $3-8$ \\
\hline $\begin{array}{c}\text { Bituminous content } \\
\% \text { by mass of total } \\
\text { mix }^{2}\end{array}$ & Min 4.5 & Min 5.0 \\
\hline $\begin{array}{l}\text { Bituminous grade } \\
\text { (pen) }\end{array}$ & $65^{*}$ & $65^{*}$ \\
\hline
\end{tabular}

\section{Notes:}

$>$ The combined aggregates grading shall not vary from the limit on one sieve to the high limit on the adjacent sieve.

$>$ Determined by the circumstances, 80/100 penetration grade may be used as approval by the engineer.
Table 3.12 Requirements for Semi Dense Bituminous Pavements Layers

\begin{tabular}{|c|c|}
\hline $\begin{array}{c}\text { Minimum stability } \\
\left(\mathrm{kN} \text { at } 60^{0} \mathrm{c}\right)\end{array}$ & $\mathbf{8 . 2}$ \\
\hline Minimum flow (mm) & 2 \\
\hline Maximum flow (mm) & 4 \\
\hline $\begin{array}{c}\text { Compaction level } \\
\text { (Number of blows) }\end{array}$ & $\begin{array}{c}\text { 75 blows on each of the } \\
\text { two faces of the specimen }\end{array}$ \\
\hline Per cent air voids & $3-5$ \\
\hline $\begin{array}{c}\text { Per cent voids mineral } \\
\text { aggregates (VMA) }\end{array}$ & See table 500-12 \\
\hline $\begin{array}{c}\text { Per cent voids filled } \\
\text { with bitumen (VFB) }\end{array}$ & $65-78$ \\
\hline
\end{tabular}

\section{COST ANALYSIS}

Providing and laying of stress absorbing Membrane over a cracked road surface, with crack Width below $6 \mathrm{~mm}$ after cleaning with mechanical Broom, using modified binder complying with clause 521, sprayed at the rate of $9 \mathrm{~kg} 10 \mathrm{sqm}$ and spreading $5.6 \mathrm{~mm}$ crushed stone aggregates @ 0.11cum per 10sqm with hydraulic chip spreader sweeping the surface for Uniform spread of aggregates and surface finished to Conform to clause 902.

Providing and applying tack coat with bitumen emulsion Using emulsion pressure distributor at the rate of $0.20 \mathrm{~kg} / \mathrm{m}^{\wedge} 2$ on the prepared bituminous/ surface cleaned with Mechanical broom.

Providing and laying bituminous macadam $75 \mathrm{~mm}$. Thick with 100-120 TPH hot plant producing an everRage output of 75 tones per hour using crushed Aggregates of specified grading premixed with Bituminous binder 60/70@3.3\% of mix, transported, to site lad over a previously prepared surface with Pavers finisher to the required grade, level and Alignment and rolled as per clause 501.6 and 501.7 to Achieve the desired compaction, add $15 \%$ undulations.

Providing and laying semi dense bituminous Concrete with 100-120 TPH batch type HMP Producing an Average output of 75 tones per hour using crushed Aggregates of specified grading premixed with bituminous Binder @5 percent of mix and filler transport

Construction of embankment with approved material, obtained from borrow pits with all lifts and leads transporting to site spreading grading to required 
slope and Compacting to meet requirement of table 300-2.

Pavement center line markings $10 \mathrm{~cm}$ wide with hot applied. Thermoplastic material completes as per drawing and technical Specification clause 803 and irc-35. Construction of drain both side of road in $\mathrm{km}$ 01 and 02 . Supply \& fixing of $80 \mathrm{~mm}$ thick I shaped mechanically Compressed inter locking cement concrete pavers block Manufactured by high pressure by \& controlled vibration, Machine having plan dimension 200* $(160+120 \mathrm{~mm})$ with mini Mum 5mm thick topping of O.P cement mixed with $25 \%$ marble Powder. The completion strength of concrete pavers blocks Shall not be less than $30 \mathrm{MPa} \& 4.5 \mathrm{~kg} / \mathrm{no}$. including cost all Material lab our T\&P etc. required for proper completion of Work as directed by engineer-in-change. Over $20 \mathrm{~cm}$ GSB, $25 \mathrm{~cm}$ WMM $\& 3 \mathrm{~cm}$ sand cushion.

\subsection{Analysis of rate emulsion supply from Mathura (W.e.f.16/07/2017)}

\section{Bitumen emulsion M.S.}

1. Rate at refinery Ex Amousi New Drum $200 \mathrm{~kg}$

Excise Duty@14 on A

Education cess@3\% on B

Cartage from Total $335 \mathrm{KM} @ 1.752 / \mathrm{MT} / \mathrm{KM}$

Deducted Drum 5 No.@300.0

\subsection{Modified Bitumen Grade CRMB-55}

1. Rate at refinery (Mathura)

Excise Duty@14\% On A

Education cess@3\% on B
28804.00 A

$4032.56 \mathrm{~B}$

120.98

32957.54

Cartage from Mathura (depot) to KM 53 of NH-29E

Total 768x2=1536 Km@1.752

\subsection{Bitumen Grade 60/70}

1. Rate at refinery (Mathura)

Excise Duty @ 14\% on A

Education cess@3\% on B

Total

Total

Say Rs.

Sub Total
$2726.11 \mathrm{~A}$

$3818.66 \mathrm{~B}$

114.56

$31209.33 \mathrm{C}$

586.92

31796.25

1500.00

30296.25

30296.20 per MT.
2691.07

35648.61

35648.60 per MT.

$27070.00 \mathrm{~A}$

$3789.80 \mathrm{~B}$

113.69

Sub Total $\quad 30973.49 \mathrm{C}$

Cartage from Mathura (depot) to KM 52 of NH-29E

Total 768x2=1536 Km@1.752

$\begin{array}{ll}\text { Total } & 2691.07 \\ \text { Total } & 33664.57 \\ \text { Say Rs. } & \mathbf{3 3 6 6 4 . 6 0} \text { per }\end{array}$

\section{RESULTS AND DISCUSSION}

\subsection{Road Construction Costs}

Road Construction Costs are dependent on several factors like - Width of the Road, Load Factor, Traffic
Handling capacity, weather conditions in the region etc. All these factors are essential for deciding the technical specifications of any road. 
Essentially you have to understand that a road is only $30 \%$ of what you see (the black portion on the top), rest of the costs $\&$ road elements are hidden below the black top. There are several elements below the blacktop portion which keeps the road stable while you drive car or while it rains.

In India, roads have been categorized into several buckets depending on several things...

$>$ Single Lane Roads (Usually those rural roads which connects villages to the nearest highways or towns), these are usually the ones which have very low traffic and they need to bear the load of lighter vehicles. Hence these are the really cheaper ones. And one can assume them to be somewhere around Rs $30 \sim 35$ Lac Per KM.

$>$ Double Lane Rural Roads, which is essentially double of the single lane roads.

Urban Roads, with double lanes which are capable of handling heavier weights ( $~ 33$ tonnes) would cost somewhere near 1 Crore per KM (+/- 10\%). The costs would also fluctuate based on the geographical uniqueness, like if the region has Back Cotton Soil, then the whole soil needs to be replaced and filled with some other soil or create an alternate arrangement to prepare the base of the road. Or if the road is adjoining a river stream or a canal, the base needs to be prepared by putting more soil and compress it before laying the black top. In such cases the costs may run up to twice the usual costs. (Technical specification is the key)

The Expressways and the highways, where you usually drive your cars at $100+\mathrm{KMPH}$. They have multiple lanes (usually 3-8 each side), and usually they have the best of the time technology being used. Such roads have usually a concrete base upon which rests the black top. And all this is done using the best available machines. Usually the cost of building such roads will start from 6 7 Crores Per KM and goes in the range $20 \sim 25$ crores per KM. [Keep in mind that these costs are separate from the cost of acquiring the land to build these roads.

\subsection{Road Construction Costs per kilometer} Name of division - Ty. D.C.U. (NH) P.W.D Etah Name of circle $-26^{\text {th }}$ circle (NH) P.W.D Luck now

Name of work: "QUALITY MANAGEMENT OF NH 31 FROM ETAH TO KASGANJ IN UP",

Table 5.1 Road Construction Costs (NH-31)

\begin{tabular}{|c|c|c|c|c|c|c|c|c|c|c|c|c|c|}
\hline \multirow[b]{2}{*}{$\begin{array}{l}\text { Km } \\
\text { no }\end{array}$} & \multirow[b]{2}{*}{$\begin{array}{l}\text { Name } \\
\text { Of } \\
\text { quarry }\end{array}$} & \multirow[b]{2}{*}{$\begin{array}{l}\text { Name of } \\
\text { material }\end{array}$} & \multirow{2}{*}{\multicolumn{3}{|c|}{$\begin{array}{l}\text { Quarry rate } \\
\text { exclusive } \\
\text { Loading charges }\end{array}$}} & \multicolumn{3}{|c|}{ Distance in km } & \multirow{2}{*}{$\begin{array}{l}\text { Cost of } \\
\text { cartages } \\
\text { excluding } \\
\text { c. p }\end{array}$} & \multirow[b]{2}{*}{$\begin{array}{l}\text { Total of } \\
\text { column } \\
6+10\end{array}$} & \multirow{2}{*}{$\begin{array}{l}\text { Rate } \\
\text { rounded } \\
\text { up to } 10 \\
\text { paisa }\end{array}$} & \multirow{2}{*}{\multicolumn{2}{|c|}{ remarks }} \\
\hline & & & & & & $\mathbf{K}$ & $\mathbf{P}$ & Total & & & & & \\
\hline 1 & 2 & 3 & 4 & 5 & 6 & 7 & 8 & 9 & 10 & 11 & 12 & 13 & $\mathrm{RS}$ \\
\hline 53 & Dala & $\begin{array}{l}25-10 \mathrm{~mm} \\
\text { Stone grit }\end{array}$ & 700 & 19 & 681 & 0 & 374 & 374 & 1232.33 & 1913.33 & 1913.33 & \multicolumn{2}{|c|}{ Cartage for dalla } \\
\hline 53 & Dala & $\begin{array}{c}10-5 \mathrm{~mm} \\
\text { stone grit }\end{array}$ & 340 & 19 & 321 & 0 & 374 & 374 & 1232.33 & 1553.33 & 1553.3 & $\begin{array}{c}1 \mathrm{~km} \text { to } \\
100^{\text {th }} \mathrm{km}\end{array}$ & 533 \\
\hline 53 & Dala & $\begin{array}{l}9.5-4.75 \mathrm{~mm} \\
\text { stone got } \\
(11.2 \mathrm{~mm})\end{array}$ & 325 & 19 & 306 & 0 & 374 & 374 & 1232.33 & 1538.33 & 1538.3 & $\begin{array}{c}\mathrm{Km} 101 \text { to } \\
374(274) \\
@ \mathrm{Rs} \\
3.0 / \mathrm{KM} \\
\end{array}$ & 823 \\
\hline 53 & Dala & $\begin{array}{c}4.75 \mathrm{~mm} \\
\text { and below } \\
(5.60 \mathrm{~mm} \\
\text { stone grill }) \\
\end{array}$ & 300 & 19 & 281 & 0 & 374 & 374 & 1232.33 & 1513.33 & 1513.3 & So total & 1355.7 \\
\hline 53 & Dala & Stone dust & 180 & 19 & 161 & 0 & 374 & 374 & 1232.33 & 1393.33 & 1393.3 & $\begin{array}{l}\text { Less c.p } \\
9.10 \%\end{array}$ & 123.37 \\
\hline 2 & Butwal & Coarse sand & 690 & 19 & 671 & 0 & 5 & 5 & 94.45 & 765.45 & 765.5 & $\begin{array}{c}\text { Net } \\
\text { cartage }\end{array}$ & 1232.33 \\
\hline 2 & Butwal & $\begin{array}{c}19 \mathrm{~mm} \text { size } \\
\text { grit }\end{array}$ & 1040 & 19 & 821 & 0 & 5 & 5 & 94.45 & 1113.45 & 1115.5 & \multicolumn{2}{|c|}{$\begin{array}{l}\text { Cartage for Butwal } \\
\text { in } \mathrm{km}-2\end{array}$} \\
\hline 2 & Butwal & $\begin{array}{c}22-4-53 \mathrm{~mm} \\
\text { stone } / 40 \\
\mathrm{~mm} \\
\text { aggregates } \\
\end{array}$ & 890 & 19 & 871 & 0 & 5 & 5 & 94.45 & 965.45 & 965.4 & $\begin{array}{c}1^{\text {st }} \mathrm{km} \text { to } \\
6^{\text {th }} \mathrm{km}\end{array}$ & 103.9 \\
\hline
\end{tabular}


International Journal of Trend in Scientific Research and Development (IJTSRD) ISSN: 2456-6470

\begin{tabular}{|c|c|c|c|c|c|c|c|c|c|c|c|c|c|}
\hline 2 & Butwal & $\begin{array}{c}45-63 \mathrm{~mm} \\
\text { stone ballast } \\
\text { (53mm to } \\
26.5 \mathrm{~mm} \text { ) }\end{array}$ & 860 & 19 & 841 & 0 & 5 & 5 & 94.45 & 935.45 & 935.4 & $\begin{array}{c}\text { Less c.p } \\
1 \%\end{array}$ & 9.4549 \\
\hline 2 & Butwal & $\begin{array}{l}\text { GSB(RBM) } \\
\text { Grade-1 }\end{array}$ & 690 & 19 & 671 & 0 & 5 & 5 & 94.45 & 765.45 & 765.4 & $\begin{array}{c}\text { Net } \\
\text { cartage }\end{array}$ & 94.45 \\
\hline 2 & Sukrut & $\begin{array}{c}45 \mathrm{~mm} \text { to } \\
63 \mathrm{~mm} \text { stone } \\
\text { ballas }\end{array}$ & 350 & 19 & 331 & 0 & 365 & 365 & 1207.79 & 1538.79 & 1538.8 & \multicolumn{2}{|c|}{$\begin{array}{l}\text { Cartage for sukrut in } \\
\mathrm{km} 2\end{array}$} \\
\hline 2 & Sukrut & $\begin{array}{l}224-53 \mathrm{~mm} \\
\text { stone ballast }\end{array}$ & 385 & 19 & 366 & 0 & 365 & 365 & 1207.79 & 1573.79 & 1573.8 & $\begin{array}{l}1^{\text {st }} \mathrm{km} \text { to } \\
100^{\text {th }} \mathrm{km}\end{array}$ & 533.7 \\
\hline 2 & sukrut & Store door & 750 & 19 & 731 & 0 & 5 & 5 & 94.50 & 825.5 & 825.50 & $\begin{array}{c}101 \text { to } 365 \\
\text { (265 km) } \\
\text { @ } 3.0 / \mathrm{k}\end{array}$ & 795 \\
\hline & & & & & & & & & & & & So total & 1328.7 \\
\hline & & & & & & & & & & & & $\begin{array}{l}\text { Less c.p } \\
9.1 \%\end{array}$ & 120.912 \\
\hline & & & & & & & & & & & & $\begin{array}{c}\text { Net } \\
\text { cartage }\end{array}$ & 1207.79 \\
\hline
\end{tabular}

\section{Certificate}

1. Quarry rate are approved by $26^{\text {th }}$ circle P.W.D marzipan.

2. Cartage rate are approved by $4^{\text {th }}$ circle P.W.D luck now.

3. Distance taken by shortest route frame quarry.

4. Transportation by road is cheaper than rail.

5. Quarry rates are from approved quarry \& RMR rates are minimum.

Table 5.2 providing and Laying 80 Mm Inert locking Pavers Including \& L GSB-Grade 1200 Mm Thick and Coarse C sand Cushions of $20 \mathrm{~mm}$

\begin{tabular}{|c|c|c|c|c|c|c|}
\hline S. no & & Description & Quantity & unit & Rate RS & Cost RS \\
\hline 1 & $1 * 1 * 0.56$ & Earth work in excavation & 0.56 & cum & 98.09 & 54.88 \\
\hline 2 & $1 * 0.03$ & $\begin{array}{c}\text { Providing and laying sand cushion } \\
\text { (gorse sand) }\end{array}$ & 0.03 & cum & 1162.10 & 34.86 \\
\hline & & Material +lab our rate $=1137.10+25=1162.10$ & & & 1280.30 & \\
\hline 3 & P\&LG.S. J & $1 * 0.20$ & 0.20 & cum & 1397.00 & 279.40 \\
\hline 4 & P\&LWMM & $1 * 1.00 * 0.25$ & 0.25 & cum & 2729.30 & 662.33 \\
\hline 5 & $\begin{array}{c}\text { Supply of } \\
\text { interlocking }\end{array}$ & $1 * 35$ & 35 & Nos & 13.00 & 455.00 \\
\hline 6 & Laying of & $1 * 1.00$ & 1.00 & M2 & 58 & 5800 \\
\hline & & & & & total & 1382.47 \\
\hline & & & & & say & 1564 \\
\hline & & & & & Per sqm & $1237=48$ \\
\hline
\end{tabular}

Name of work: I.R.Q.P of nh-29 extension in km 51, 52,53,54,55

Table 5.3 Analysis of Rate of Drain Item no.7 per RM

\begin{tabular}{|c|c|c|c|c|c|c|c|c|}
\hline Sr. No & Item of work & no & L & b & H/D & qty & rate & Amount \\
\hline 1 & $\begin{array}{c}\text { Earth work in excavation of foundation } \\
\text { of structure as per drawing and } \\
\text { technical specification of shoring and } \\
\text { etc. complete in all respect. }\end{array}$ & 1 & 1.00 & 1.3 & 1.150 & 1.495 & 44.70 & 66.80 \\
\hline 2 & $\begin{array}{c}\text { Plain cement concrete 1:2:6 nominal } \\
\text { mix in foundation with crushed stone } \\
\text { aggregate 40mm nominal size } \\
\text { mechanically mixed placed in }\end{array}$ & 1 & 1.00 & 1.3 & 0.150 & 0195 & 3361.00 & 655.395 \\
\hline
\end{tabular}


International Journal of Trend in Scientific Research and Development (IJTSRD) ISSN: 2456-6470

\begin{tabular}{|c|c|c|c|c|c|c|c|c|}
\hline & $\begin{array}{l}\text { foundation and compacted by vibration } \\
\text { including curing for. (S.L.NO-4) }\end{array}$ & & & & & & & \\
\hline 3 & $\begin{array}{l}\text { Brick masonry work in cement mortar } \\
\text { 1:3 in foundation complete excluding } \\
\text { portion and plastering's per drawing } \\
\text { and technical specification (S.L.N.O-4) }\end{array}$ & $\begin{array}{c}1 * \\
2\end{array}$ & 1.00 & $\begin{array}{c}1265 \\
(0.23+0.3 \\
8)\end{array}$ & 1 & 53 & 3614.00 & 1915.42 \\
\hline 4 & $\begin{array}{l}\text { Plastering with cement mortar (1:3) or } \\
\text { brick work in sub-structure as per } \\
\text { technical specification (S.L.NO)-3(A)) }\end{array}$ & $\begin{array}{c}1 * \\
2\end{array}$ & 1.00 & 1.00 & & 2.00 & 80.00 & 160.00 \\
\hline 5 & $\begin{array}{l}2.5 \mathrm{~mm} \text { thick PCC } 1: 2: 4(1 \text { cement }: 2.5 \\
\text { coarse sand }: 3.5 \text { graded stone } \\
\text { aggregates of } 12.5 \mathrm{~mm} \text { nominal size) in } \\
\text { flooring with cement course sand \& } \\
\text { 20mm kabrai grit. (S.L. No-9) (A) }\end{array}$ & $\begin{array}{c}1 * \\
1\end{array}$ & 1.00 & 96.00 & & 9.60 & 1375.00 & 1320.00 \\
\hline 6 & $\begin{array}{l}\text { Providing and placing } 2.5 \mathrm{~cm} \text { thick } \\
\text { precast RCC cover of grade } \mathrm{M} / 25 \text { of } \\
\text { size } 1300 \mathrm{~mm}^{*} 1000 \mathrm{~mm} \text { over drain. }\end{array}$ & 1 & 1.00 & 1.000 & & 1.00 & 853.50 & $853=50$ \\
\hline & $+2+2+111$ & & & 70 & & & total & 5631.10 \\
\hline & & 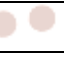 & 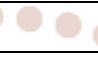 & & & & Say Rs & 5631.00 \\
\hline & & & & & & & $\begin{array}{c}\text { Per } \\
\text { R/M }\end{array}$ & $4911=11$ \\
\hline
\end{tabular}

\section{Materials}

1. The rates are exclusive of contractor's profit for item. No. one only $5 \%$ contractor profits may be given while taking the supply through some agency other than a direct supplier (Kiln. owner)

2. The rates include cartage for $1^{\text {st }} 8 \mathrm{~km}$ for item no $1.2 \& 40$ omly. Other rates are for whole district except for item 3 and39 $\mathrm{B}$ which is quarry rates.
3. The rates are exclusive of sales tax which shall be applicable except item 1,2 which are inclusive of sales tax.

While taken supplies minimum bulk age will be deducted as below:

1. Course sand and cinder $15 \%$

2. Local sand and fine sand $20 \%$

3. Surkhi $15 \%$

Table 5.4 Rates of Material

\begin{tabular}{|c|c|c|c|c|}
\hline S. No. & Materials & $\begin{array}{c}\text { PWD } \\
\text { Specification }\end{array}$ & Unite & Rates \\
\hline 1 & 2 & 3 & 4 & 5 \\
\hline \multicolumn{5}{|c|}{ (n) 1 Bricks } \\
\hline A & $\begin{array}{l}\text { Class } 150 \text { sub class 'A' District } \\
\text { Gorakhpur \& Maharajganj }\end{array}$ & 1.1 & Per 1000 Nos & 3600.00 \\
\hline B & $\begin{array}{c}\text { Sub class 'B' } \\
\text { Straight over (Burnt)Bricks }\end{array}$ & 1.1 & -Do- & 3500.00 \\
\hline $\mathrm{C}$ & Brick Bats (over burnt bricks) & & $\begin{array}{l}\text { Per cubic } \\
\text { meter }\end{array}$ & 525.00 \\
\hline \multicolumn{5}{|c|}{ 2. BRICKS BALLAST (From class150 and over burnt brick only) } \\
\hline A & $40 \mathrm{~mm}$ gauge & 1.2 & Per cum & 650.00 \\
\hline B & 45-63 mm gauge & & -Do- & 610.00 \\
\hline $\mathrm{C}$ & Rubbish & & -do- & 215.00 \\
\hline \multirow{2}{*}{\multicolumn{5}{|c|}{ 3. STONE BALLAST/GRIT (Loaded truck but cp. Toll tax, stacking. S. t. extra }} \\
\hline & & & & \\
\hline \multirow[t]{2}{*}{ A } & $19 \mathrm{~mm}$ size/16-22 mm size & & Per cum & 840 \\
\hline & 10-16 mm size shingle & & -do- & 820.00 \\
\hline
\end{tabular}


International Journal of Trend in Scientific Research and Development (IJTSRD) ISSN: 2456-6470

\begin{tabular}{|c|c|c|c|c|}
\hline & $10 \mathrm{~mm}$ size shingle & & -do- & 790.00 \\
\hline & $11.2 \mathrm{~mm}$ size shingle & & -do- & 790.00 \\
\hline & $13.132 \mathrm{~mm}$ size shingle & & -do- & 820.00 \\
\hline & 6mm size (P Gravel) & & -do- & 720.00 \\
\hline & GSB(RBM) Grade-1 & & -do- & 700.00 \\
\hline $\mathrm{B}$ & Butwal Coarse sand & & -do- & 690.00 \\
\hline \multirow[t]{4}{*}{$\mathrm{C}$} & Butwal Stone Ballast Crushed & & -do- & 790.00 \\
\hline & $22.4-53 \mathrm{~mm}$ size & & -do- & 1040.00 \\
\hline & $45-62 \mathrm{~mm}$ size & & -do- & 990.00 \\
\hline & 45-90mm size & & -do- & 820.00 \\
\hline \multirow[t]{7}{*}{$\mathrm{D}$} & Butwal Crushed Grit & & & \\
\hline & $10 \mathrm{~mm}$ crushed & & -do- & 1040.00 \\
\hline & $13,13.20 \mathrm{~mm}$ crushed & & -do- & 990.00 \\
\hline & $11.20 \mathrm{~mm}$ crushed & & -do- & 945.00 \\
\hline & $5.6 / 6 \mathrm{~mm}$ crushed & 0.0 & -do- & 780.00 \\
\hline & $2.36 \mathrm{~mm}$ crushed & & -do- & 750.00 \\
\hline & Stone dust & Gienthe & - do- & 720.00 \\
\hline \\
\hline A. & $10.00 \mathrm{~cm}$ mean die $\quad 1.18 .21 .18 .2$ & & & $\begin{array}{l}\text { as per forest } \\
\text { Department }\end{array}$ \\
\hline B. & $12.50 \mathrm{~cm}$ mean die $\quad 1.18 .2$ & \begin{tabular}{l|l|l|l}
+5 & 0 \\
\end{tabular} & -do- & -do- \\
\hline 5. & Cement Portland (ordinary) & 1.8 .2 & $\begin{array}{c}\text { per bag of } \\
50 \mathrm{~kg}\end{array}$ & 260.00 \\
\hline 6. & White cement (JK or Birla Brand) & - do- & - do- & 600.00 \\
\hline 7. & Cinder of rient & in $1-14$ entil & per Cum & 250.00 \\
\hline A. & Distemper (dry of best quality) tract & 1.23 .1 & per $\mathrm{kg}$ & D.I. Rare Contract \\
\hline B. & $\begin{array}{c}\text { Distemper (Oil) in paste of best } \\
\text { quality }\end{array}$ & 1.23 .1 & $-\mathrm{do}-$ & $\begin{array}{l}\text { As per U.P. } \\
\text { Govt. }\end{array}$ \\
\hline \multicolumn{5}{|c|}{$\begin{array}{lll} & \text { Glass ordinary cut to size (Granular) }\end{array}$} \\
\hline A. & $3 \mathrm{~mm}$ think & & p. sq. m & 190.00 \\
\hline B. & $4 \mathrm{~mm}$ think & $2400=04 / 0$ & -do- $\quad$ & 260.00 \\
\hline C. & $5.5 \mathrm{~mm}$ think & +2 & - do- & 320.00 \\
\hline D. & $3 \mathrm{~mm}$ think glass strips $22 \mathrm{~mm}$ wide & $200+2$ & per R.M & 3.40 \\
\hline E. & $3 \mathrm{~mm}$ think glass strips $35 \mathrm{~mm}$ wide & 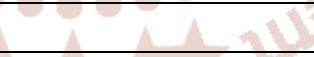 & per R.M & 5.00 \\
\hline \\
\hline A. & Katni & $1.12 .1=$ & p. Qtl. & 310.00 \\
\hline B. & Sal khan & 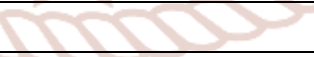 & -do- & 300.00 \\
\hline C. & White washing lime & & -do- & 340.00 \\
\hline \multirow[t]{5}{*}{ 11. A. } & M.S Flats & & -do- & 3400.00 \\
\hline & Channels & & -do- & 3500.00 \\
\hline & Angle & 1.7 .3 & -do- & 3400.00 \\
\hline & Beam & & -do- & 3900.00 \\
\hline & Plates & & -do- & 3800.00 \\
\hline B. & M.S Rounds & 1.7 .2 & -do- & 3450.00 \\
\hline C. & Ribbed/for steel & 1.7 .5 to 1.7 .7 & -do- & 3450.00 \\
\hline \multicolumn{5}{|c|}{ 12. Marble-chips $3 \mathrm{~mm}$ to $5 \mathrm{~mm}$ size } \\
\hline A. & white & & -do- & 185.00 \\
\hline B. & Black or Colored & & -do- & 195.00 \\
\hline 13. & Marble dust (200 mesh) & & - do- & 185.00 \\
\hline 14. & Paints enamels and varnishes & 1.32 & per lift. As per & DI rate Contract \\
\hline
\end{tabular}


International Journal of Trend in Scientific Research and Development (IJTSRD) ISSN: 2456-6470

\begin{tabular}{|c|c|c|c|c|}
\hline & & & U.P. govt & \\
\hline \multicolumn{5}{|c|}{ 15. Pipes A.C. Rain water } \\
\hline A. & $50 \mathrm{~mm}$ intimal die & 4.41 .1 & per R.M. & 48.00 \\
\hline B. & $100 \mathrm{~mm}$ intimal die & 4.41 .2 & - do- & 65.00 \\
\hline 16. A. & Local sand (for whole District) & $1.9 .1^{\top}$ & per cum & 170.00 \\
\hline B. & Fine sand (quarry rate) & - do- & & 200.00 \\
\hline 17. & Surkhi & 1.13 & per cum & 350.00 \\
\hline \multicolumn{5}{|c|}{ 18. Indian Salwood chaukhat section cut to size } \\
\hline A. & Up to 1.2 -meter length & 1.5 .1 to 1.5 .3 & -do- & As per forest Deptt \\
\hline B. & 1.20 meter to 2.13 & -do- & -do- & -do- \\
\hline C. & 2.13 meter to 2.75 -meter length & -do- & -do- & -do- \\
\hline \multicolumn{5}{|c|}{ 19. Teak wood } \\
\hline A. & Up to 1.22 -meter length & & -do- & As per forest Deptt \\
\hline
\end{tabular}

Table 5.5 Earth Work Cost

\begin{tabular}{|c|c|c|c|c|c|}
\hline $\begin{array}{l}\text { SL. } \\
\text { NO }\end{array}$ & DESCRIPTION & UNIT & PER & $\begin{array}{l}\text { OVER } \\
\text { ALL } \\
\text { RATE }\end{array}$ & $\begin{array}{l}\text { RATES } \\
\text { LABOUR } \\
\text { RATE } \\
\end{array}$ \\
\hline 1 & 2 & 3 & 4 & 5 & 6 \\
\hline 251 & $\begin{array}{l}\text { Excavation of foundation in ordinary soil (Loam clay or } \\
\text { sand) including lift up to } 1.50 \text { meter and lead up to } 30 \text { meter } \\
\text { and Including filling, watering and ramming of excavated } \\
\text { earth into the trenches or into the trenches or into the space } \\
\text { between the building and sides foundation trenches. }\end{array}$ & $\begin{array}{l}\text { Cubic } \\
\text { meter }\end{array}$ & & 52.00 & 46.00 \\
\hline 252 & $\begin{array}{c}\text { As in item (251) above but excavation in soil mixed with } \\
\text { moor am and /or shingles or kanker etc. requiring. The use of } \\
\text { special tools and plants as pickaxes sabbales meter } \\
\text { (Crowbars) with hammers etc. }\end{array}$ & $\begin{array}{l}\text { Cubic } \\
\text { meter }\end{array}$ & $\begin{array}{l}\text { Per } \\
\mathrm{m} 3\end{array}$ & 55.60 & 49.20 \\
\hline 253 & $\begin{array}{l}\text { Earth in cutting or in embankment in ordinary soil (Loam, } \\
\text { clay or sand) excavation to in the form of pit Not exceeding } \\
\text { to be in the form of pit nit exceeding } 50 \mathrm{~cm} \text { in depth and earth } \\
\text { embankment to be in } 20 \mathrm{~cm} \text {. meter. layers including the } \\
\text { ramming to and dressing the surface to required levels slopes } \\
\text { and also including } 1.50 \text {-meter Lift and } 30 \text {-meter lead. The } \\
\text { earth from cutting to be used in Making embankment or to be } \\
\text { deposited as spoil bank within } 30 \text {-meter distance by the } \\
\text { engineer in charge. }\end{array}$ & & & 44.70 & 39.50 \\
\hline 254 & Add to items (251 to 253 ) for every additional & & & & \\
\hline
\end{tabular}

Table 5.6 Linear length of KM'S

\begin{tabular}{|c|c|c|c|c|}
\hline SI NO & Kilometer no & Length(meter) & Width (meter) & Area (sqm) \\
\hline 1 & $51,(0.00$ to 0.790$)$ & 790 & 7 & 5530 \\
\hline 2 & $51,(0.790$ to 1.00$)$ & 210 & 10 & 2100 \\
\hline 3 & 52 & 1000 & 7 & 7000 \\
\hline 4 & 53 & 1000 & 7 & 7000 \\
\hline 5 & 54 & 1000 & 7 & 7000 \\
\hline 6 & 55 & 1500 & 7 & 10500 \\
\hline $\begin{array}{c}\text { For junction and link roads average } \\
\text { width 14.00+3.5)2=8.75, total no of } \\
\text { link roads=7 }\end{array}$ & & 3 & 8.75 & 183.75 \\
\hline & & & & \\
\hline
\end{tabular}


Table 5.7 Chart of Renewal

\begin{tabular}{|c|c|c|c|c|c|}
\hline S. NO & Kilometers & Crust (in $\mathbf{m m}$ ) & Type of surface & year of renewal & remarks \\
\hline 1 & 51 & 300 & SDBC & $3-A p r$ & \\
\hline 2 & 52 & 300 & SDBC & $3-A p r$ & \\
\hline 3 & 53 & 300 & SDBC & $3-A p r$ & \\
\hline 4 & 54 & 300 & SDBC & $3-A p r$ & \\
\hline 5 & 55 & 300 & SDBC & $3-A p r$ & \\
\hline
\end{tabular}

\subsection{Estimation}

The unit cost of road construction in dollars per kilometer is the sum of the subunit costs of the road construction activities. Road construction unit costs are estimated by dividing the machine rates by the production rates for the various activities involved in road construction. The road construction activities considered here are surveying, clearing and grubbing, excavation, surfacing, and drainage.

Name of work: I, R, Q, P Of NH-29 extension in Km 51,52,53,54,55

Table 5.8 cost estimation of $\mathrm{NH}-29$

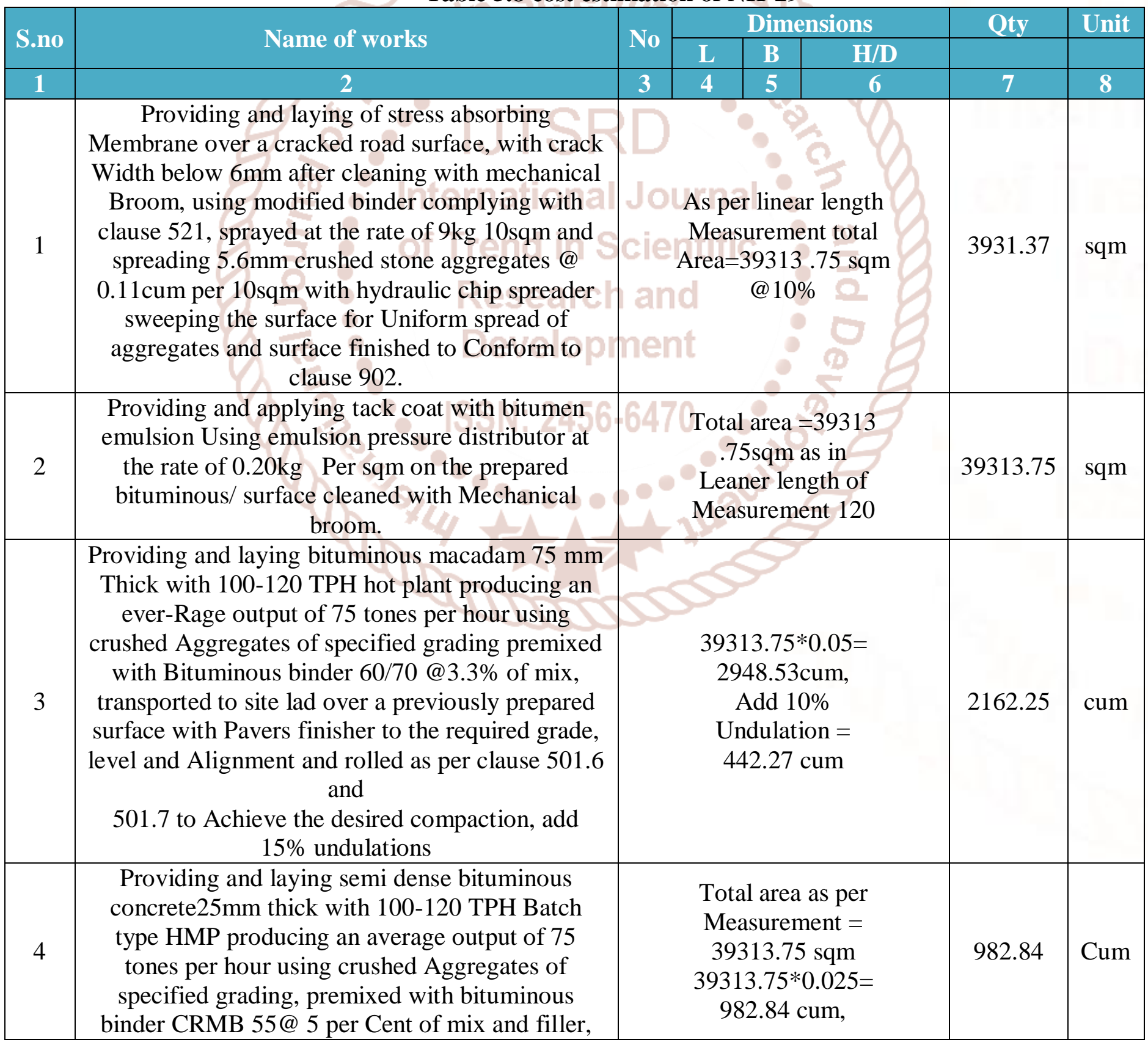




\begin{tabular}{|c|c|c|c|c|c|c|c|}
\hline & $\begin{array}{l}\text { transporting the hot mix to work site laying with a } \\
\text { hydrostatic Pavers finisher with sensor control to } \\
\text { the required grade, level and alignment, rolling } \\
\text { with smooth wheeled vibratory and tandem roller } \\
\text { to } 508 \text { complete } \\
\text { in respects add } 15 \% \text { undulation. }\end{array}$ & & & & & & \\
\hline \multirow[t]{8}{*}{5} & $\begin{array}{l}\text { Construction of embankment with approved } \\
\text { material Obtained from borrow pits with all lifts } \\
\text { and leads trans Porting to site spreading grading to } \\
\text { required slope and compacting to meet Required } \\
\text { of table } 300-2\end{array}$ & $5 \times 2$ & 1000 & 2.5 & 0.2 & & \\
\hline & In $\mathrm{Km} 76$, chainage 75.600 to 76.00 & 2 & 400 & 1.5 & 1 & 1200 & cum \\
\hline & In $\mathrm{Km} 77$, chainage 76,00 to 76.100 & 2 & 100 & 1.5 & 1 & 300 & cum \\
\hline & In $\mathrm{Km} 80$, chainage 79.600 to 80.000 & 2 & 400 & 1.5 & 1 & 1200 & cum \\
\hline & In $\mathrm{Km} 81$, chainage 80.00 to 80.600 & 2 & 600 & 1.5 & 1 & 1800 & cum \\
\hline & In $\mathrm{Km} 83$, chainage 82.600 to 83.00 & 2 & 400 & 1.5 & 1 & 1200 & cum \\
\hline & In $\mathrm{Km} 86$, chainage 85.00 to 85.800 & 2 & 800 & 1.5 & 1 & 2400 & cum \\
\hline & 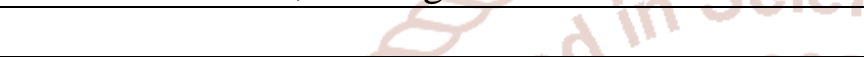 & & & & & 13000 & Sqm. \\
\hline 6 & $\begin{array}{l}\text { Making } 10 \mathrm{~cm} . \text { wide traffic line and edge line both } \\
\text { side with Thermo plats' paint } \ldots \ldots\end{array}$ & & & & & 1550.00 & Sqm \\
\hline 7 & $\begin{array}{l}\text { Construction of drain both side of road in } \mathrm{Km} \\
01 \text { and } 02\end{array}$ & & & & & 2800.00 & $\mathrm{RM}$ \\
\hline 8 & $\begin{array}{l}\text { Supply \& fixing of } 80 \mathrm{~mm} \text { thick I shaped } \\
\text { mechanically Compressed inter locking cement } \\
\text { concrete pavers Block Manufactured by high } \\
\text { pressure by \& controlled vibration Machine } \\
\text { having plan dimension } 200 *(160+120 \mathrm{~mm}) \text { with } \\
\text { mini Mum } 5 \mathrm{~mm} \text { thick topping of O.P cement } \\
\text { mixed with } 25 \% \text { marble Powder. The completion } \\
\text { strength of concrete pavers blocks Shall not be } \\
\text { less than } 30 \mathrm{MPa} \& 4.5 \mathrm{~kg} / \text { no. including cost all } \\
\text { Material labor T\&P etc. required for proper } \\
\text { completion of Work as directed by engineer-in- } \\
\text { change. Over } 20 \mathrm{~cm} \text { GSB, } 25 \mathrm{~cm} \text { WMM \& } 3 \mathrm{~cm} \\
\text { sand cushion. }\end{array}$ & $n e 2$ & 1400 & & & 7000.00 & Sqm \\
\hline
\end{tabular}

\subsection{Costing}

As the cost estimates are required at early stages of a project, considerations were given to the fact that the input data for the required regression model could be easily extracted from sketches or scope definition of the project. 
International Journal of Trend in Scientific Research and Development (IJTSRD) ISSN: 2456-6470

Table 5.9 Bill of Quantity (HH-31)

\begin{tabular}{|c|c|c|c|c|c|c|}
\hline Synod. & Particulars & Quantity & nit & ate & er & $\begin{array}{l}\text { Amount in } \\
\text { RS }\end{array}$ \\
\hline 1 & 2 & 3 & 4 & 5 & 6 & 7 \\
\hline 1 & $\begin{array}{c}\text { Providing and laying of stress absorbing } \\
\text { Membrane over a cracked road surface, with crack } \\
\text { Width below 6mm after cleaning with mechanical } \\
\text { Broom, using modified binder complying with } \\
\text { clause 521, sprayed at the rate of 9kg 10sqm and } \\
\text { spreading 5.6mm crushed stone aggregates @ } \\
\text { 0.11cum per 10sqm with hydraulic chip spreader } \\
\text { sweeping the surface for Uniform spread of } \\
\text { aggregates and surface finished to Conform to } \\
\text { clause } 902 \text {. }\end{array}$ & 7862.75 & sqm & 60.10 & per & 472551.28 \\
\hline 2 & $\begin{array}{l}\text { Providing and applying tack coat with bitumen } \\
\text { emulsion Using emulsion pressure distributor at the } \\
\text { rate of } 0.20 \mathrm{~kg} \text { Per sqm on the prepared } \\
\text { bituminous/ surface cleaned with Mechanical } \\
\text { broom. }\end{array}$ & & & 8.50 & per & 334166.88 \\
\hline 3 & $\begin{array}{l}\text { Providing and laying bituminous macadam } 75 \mathrm{~mm} \text {. } \\
\text { Thick with } 100-120 \mathrm{TPH} \text { hot plant producing an } \\
\text { ever- Rage output of } 75 \text { tones per hour using } \\
\text { crushed Aggregates of specified grading premixed } \\
\text { with Bituminous binder } 60 / 70 \text { @ } 3.3 \% \text { of mix, } \\
\text { transported, to site lad over a previously prepared } \\
\text { surface with Pavers finisher to the required grade, } \\
\text { level and Alignment and rolled as per clause } 501.6 \\
\text { and } 501.7 \text { to Achieve the desired compaction, add } \\
15 \% \text { undulations. }\end{array}$ & & 8 & & per & 14249227250 \\
\hline 4 & $\begin{array}{c}\text { Providing and laying semi dense bituminous } \\
\text { Concrete with 100-120 TPH batch type HMP } \\
\text { Producing an Average output of } 75 \text { tones per hour } \\
\text { using crushed Aggregates of specified grading } \\
\text { premixed with bituminous Binder @ } 5 \text { percent of } \\
\text { mix and filler transport. }\end{array}$ & & & 5459 & per & $8313843=56$ \\
\hline 5 & $\begin{array}{l}\text { Construction of embankment with approved } \\
\text { material, obtained from borrow pits with all lifts } \\
\text { and leads transporting to site spreading grading to } \\
\text { required slope and Compacting to meet } \\
\text { requirement of table } 300-2 \text {. }\end{array}$ & 13100.00 & sqm & 65.70 & per & 860670 \\
\hline 6 & $\begin{array}{c}\text { Pavement center line markings } 10 \mathrm{~cm} \text { wide with } \\
\text { hot applied. Thermoplastic material completes as } \\
\text { per drawing and technical Specification clause } 803 \\
\text { and irc-35. }\end{array}$ & 1650.00 & sqm & 497.3 & per & 820545.00 \\
\hline 7 & $\begin{array}{l}\text { Construction of drain both side of road in } \mathrm{km} 01 \\
\text { and } 02\end{array}$ & 2800.00 & $\mathrm{RM}$ & 5631 & per & 15766800 \\
\hline
\end{tabular}


International Journal of Trend in Scientific Research and Development (IJTSRD) ISSN: 2456-6470

\begin{tabular}{|c|c|c|c|c|c|c|}
\hline 8 & $\begin{array}{l}\text { Supply \& fixing of } 80 \mathrm{~mm} \text { thick I shaped } \\
\text { mechanically Compressed inter locking cement } \\
\text { concrete pavers block Manufactured by high } \\
\text { pressure by \& controlled vibration, Machine having } \\
\text { plan dimension } 200^{*}(160+120 \mathrm{~mm}) \text { with mini } \\
\text { Mum } 5 \mathrm{~mm} \text { thick topping of O.P cement mixed } \\
\text { with } 25 \% \text { marble Powder. The completion strength } \\
\text { of concrete pavers blocks Shall not be less than } \\
\text { 30MPa \& } 4.5 \mathrm{~kg} / \text { no. including cost all Material lab } \\
\text { our T\&P etc. required for proper completion of }\end{array}$ & & & 4911 & & 13750800 \\
\hline 9 & $\begin{array}{l}\text { Work as directed by engineer-in-change. Over } 20 \\
\mathrm{~cm} \text { GSB, } 25 \mathrm{~cm} \text { WMM \& } 3 \mathrm{~cm} \text { sand cushion. }\end{array}$ & 700 & sqm & 1237 & total & $\begin{array}{c}8659000 \\
47794971=10\end{array}$ \\
\hline
\end{tabular}

Table 5.10 Summary of Estimated Cost

\begin{tabular}{|c|c|c|}
\hline Sr NO & ITEM OF WORK & AMOUNT IN RS. \\
\hline 1 & (A) As per bill of quantity & $47794971=10$ \\
\hline 2 & Contingency @ 2.8\% on A & 1338259.19 \\
\hline & (B) Total & $49133230=29$ \\
\hline 3 & Add 1\% Quality control on B & 491332.30 \\
\hline 4 & Add 1.5\% work charge established on B & 736998.50 \\
\hline 5 & Lab our tax @ 1\% & 491332.30 \\
\hline 6 & Add 9\% agency charges on B & 4421991 \\
\hline & Total (B+SI NO.3,4,5 AND 6) & $55274884=07$ \\
\hline & SAY & $552.75 \mathrm{ACS}$ \\
\hline
\end{tabular}

6. PHOTO GALLARY

Figure 5.1 Road Excavation (NH-31)

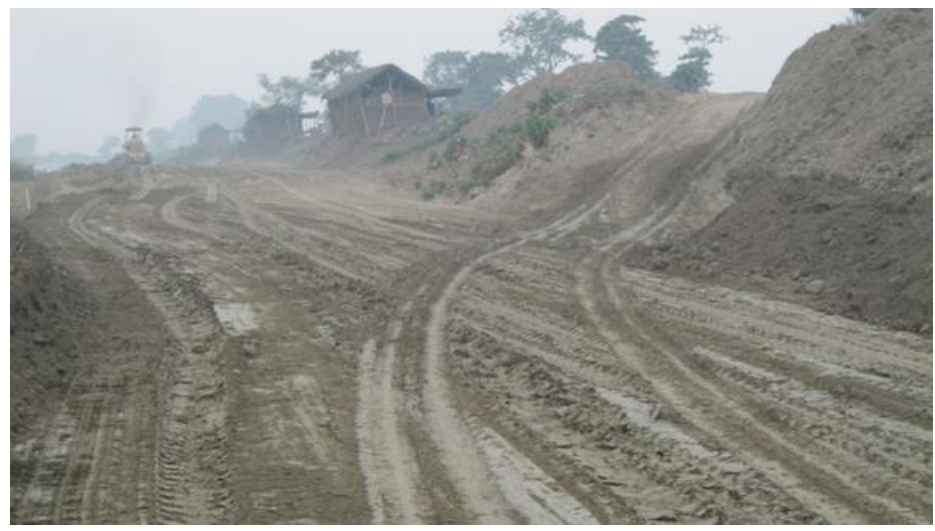

Figure 5.2 Leveling of Road (NH-31)

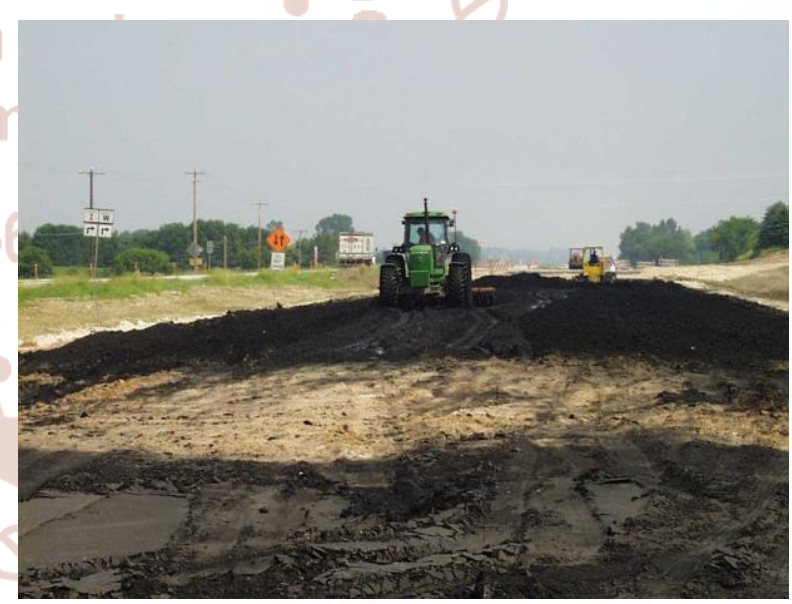

Figure 5.3 Granular Sub-Base (NH-31)

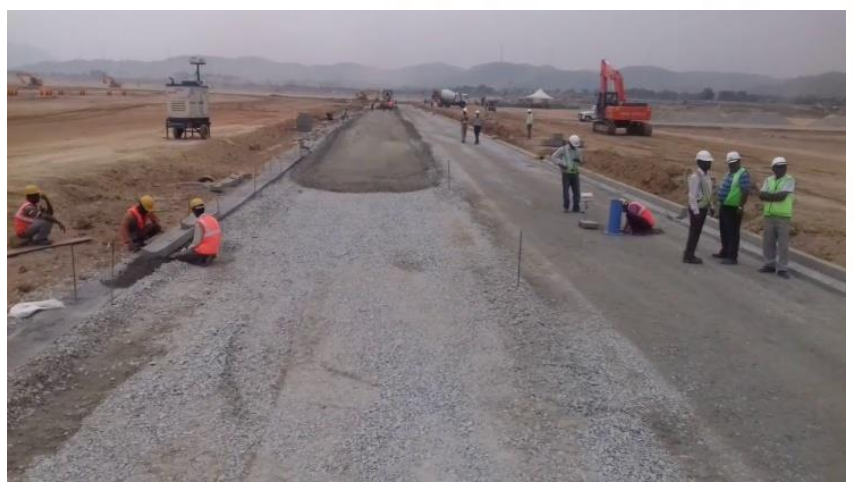

Figure 5.4 Wet mix Macadam Sub-base/Base (NH31) 


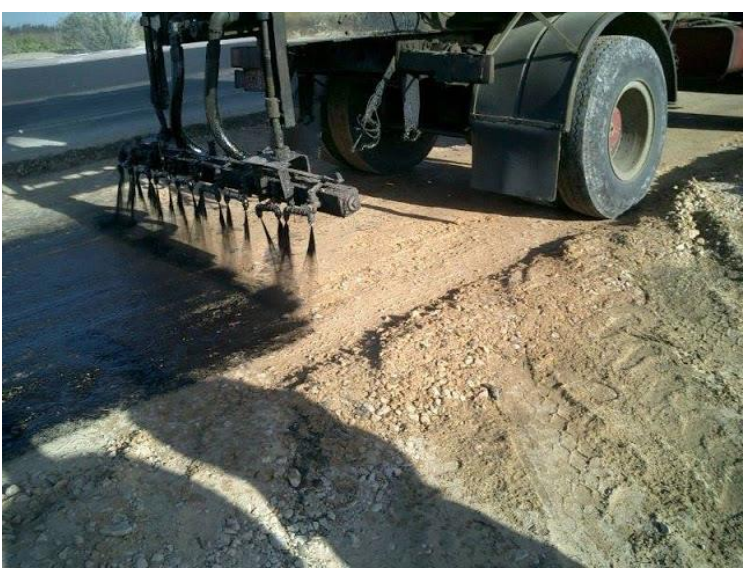

Figure 5.5 Prime Coat over Granular Base (NH31)

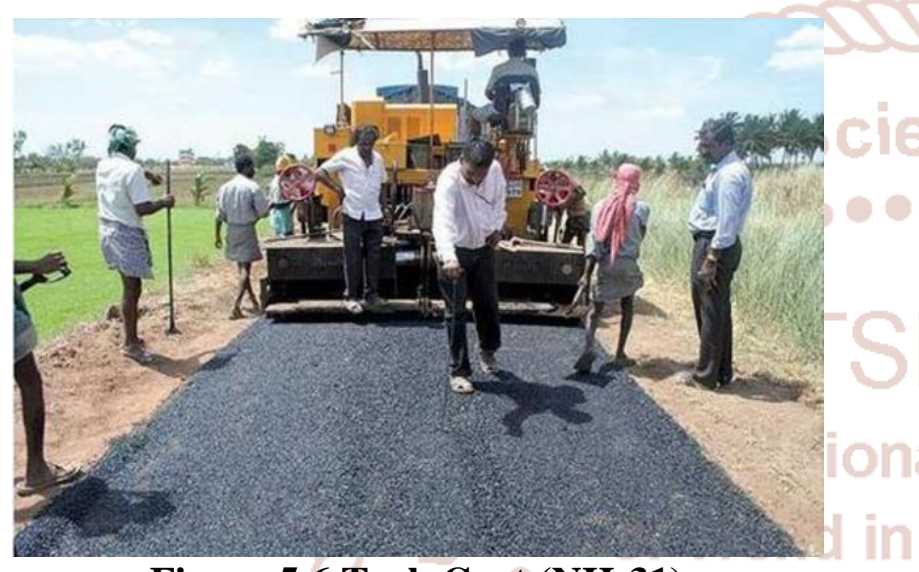

Figure 5.6 Tack Coat (NH-31)

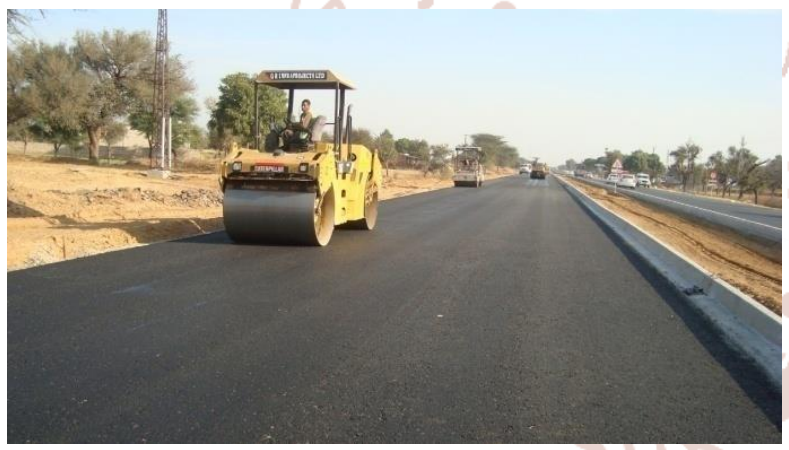

Figure 5.7 Bituminous Macadam (NH-31)

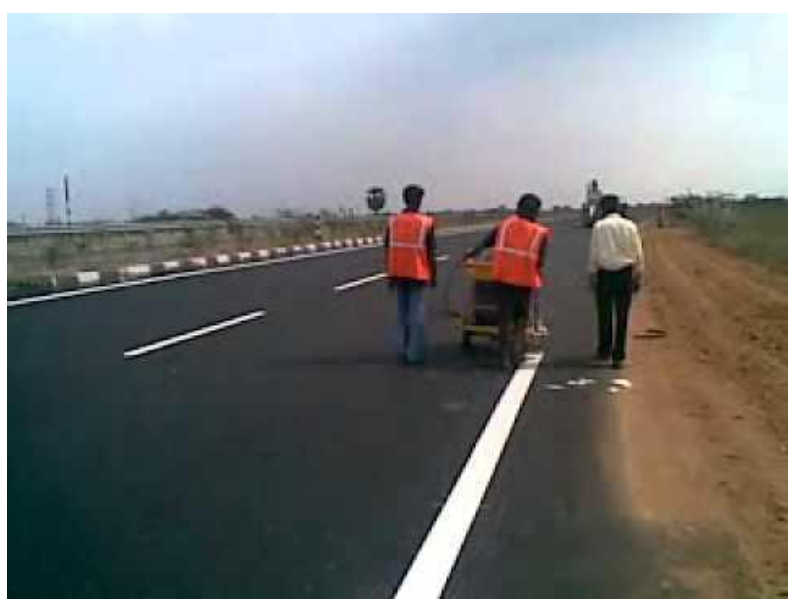

Figure 5.8 Lining of Road (NH-31)

\section{REFERENCES}

1. Niskanen, T. (1994) Safety climate in the road administration, Safety Science, 17(4), pp. 237255.

2. Gupta, J. P. and Sravat, A. K. (1998) Development and project financing of private power projects in developing countries: a case study in India. International Journal of Project Management, 16, 99-105.

3. Ahire, S. L., Dreyfus, P., 2000. The impact of design management and process management on quality: an empirical examination. Journal of Operations Management 18, 549-575.

4. McIntyre, C. \& Kirschenman, M. (2000) Survey of TQM in construction industry in upper Midwest, Journal of Management in Engineering, 16(5), pp. 67-70.

5. McKim, R. A. \& Kiani, H. (1995) Applying total quality management to the North American construction industry, Cost Engineering, 37(3), pp. 24-29.

6. Oakland, J. \& Aldridge, A. (1995) Quality management in civil and structural engineering consulting, International Journal of Quality and Reliability Management, 12(3), pp. 32-48.

7. Sommerville, J. (1994) Multivariate barriers to total quality management within the construction industry, Total Quality Management, 5(5), pp. 289-298.

8. Shou Qing Wang*1, Mohammed Fadhil Dulaimi2 And Muhammad Yousuf Aguria3 Risk management framework for construction projects in developing countries, Construction Management and Economics (March 2004) 22, $237-252$

9. Akintola Akintoye*, George McIntosh, Eamon Fitzgerald, A survey of supply chain collaboration and management in the UK construction industry

10. K. N. JHA! \& K. C. IYER!!, Critical Factors Affecting Quality Performance in Construction Projects, Total Quality Management Vol. 17, No. 9, 1155-1170, November 2006

11. Ali Jaafari, Human Factors in the Australian Construction Industry: Towards Total Quality Management,

12. Arnold, G. "Performance based specifications for road construction and materials." International 
International Journal of Trend in Scientific Research and Development (IJTSRD) ISSN: 2456-6470

Symposium on Unbound Aggregates in Roads, International Conference on Geomechanics in 5th, Nottingham, United Kingdom. 2000.

Tropical Soils, 2nd, 1988, Singapore. Vol. 1.

13. T Findlay, C. Scot, and Josée Bourdages. 1988.

"Response time of wetland biodiversity to road construction on adjacent lands." Conservation Biology 14.1 (2000): 86-94.

14. Cocks, G. C., and G. Hamory. "Road construction

15. Odeck, James. "Cost overruns in road construction-what are their sizes and determinants?" Transport policy 11.1 (2004): 4353.

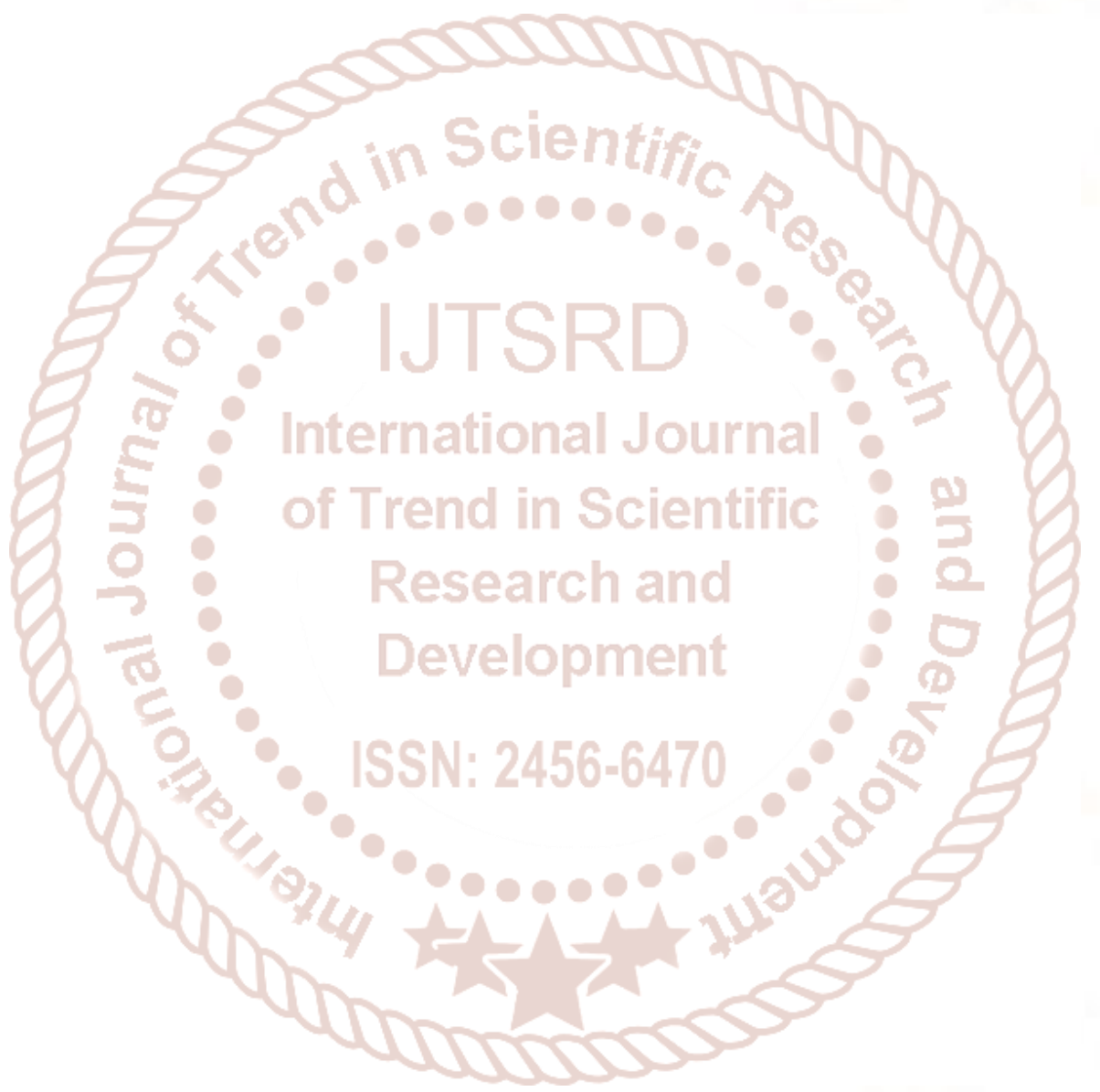

